This item was submitted to Loughborough's Research Repository by the author.

Items in Figshare are protected by copyright, with all rights reserved, unless otherwise indicated.

\title{
Foreign competition, domestic competition and innovation in Chinese private high-tech new ventures
}

PLEASE CITE THE PUBLISHED VERSION

https://doi.org/10.1057/s41267-017-0083-y

\section{PUBLISHER}

(C) Academy of International Business. Published by Palgrave Macmillan

\section{VERSION}

AM (Accepted Manuscript)

\section{PUBLISHER STATEMENT}

This work is made available according to the conditions of the Creative Commons Attribution-NonCommercialNoDerivatives 4.0 International (CC BY-NC-ND 4.0) licence. Full details of this licence are available at: https://creativecommons.org/licenses/by-nc-nd/4.0/

\section{LICENCE}

CC BY-NC-ND 4.0

\section{REPOSITORY RECORD}

Xia, Tianjiao, and Xiaohui Liu. 2017. "Foreign Competition, Domestic Competition and Innovation in Chinese Private High-tech New Ventures”. Loughborough University. https://hdl.handle.net/2134/24852. 


\title{
Foreign competition, domestic competition and innovation in Chinese private high-tech new ventures
}

\author{
Tianjiao Xia
}

School of Business and Economics, Loughborough University, Loughborough, UK.

Email: T.Xia@lboro.ac.uk

\begin{abstract}
Xiaohui Liu ${ }^{1}$
1. School of Business and Economics, Loughborough University, Loughborough, UK.

2. School of International Business, Southwestern University of Finance and Economics, Chengdu, China

X.Liu2@lboro.ac.uk
\end{abstract}

\footnotetext{
${ }^{1}$ Corresponding author.
} 


\title{
Foreign competition, domestic competition and innovation in Chinese private high-tech new ventures
}

\begin{abstract}
Competition plays an important role in creating conditions favourable to innovation. However, is this the case for all types of competition? While recognizing the importance of competition in innovation, we address this question by examining the impact of foreign and domestic competition on the innovation performance of private high-tech new ventures. We argue that the impact of foreign and domestic competition on the innovation performance of local private firms may vary, due to the different types of resource interdependence with their competitors and learning gained by private firms. To test these arguments, we conducted a multilevel analysis of 805 Chinese private high-tech firms over the period 2001-2007. Our findings suggest that foreign competition has a U-shaped relationship with the innovation performance of private firms, whereas competition from state-owned enterprises positively affects private firms' innovation performance. Our study moves beyond the debate on whether competition increases or decreases innovation by unpacking the differential effects exerted by different types of competitors on the innovation performance of local private firms in the context of a transition economy.
\end{abstract}

Keywords: resource dependence theory; foreign competition; SOE competition; innovation; multilevel analysis 


\section{INTRODUCTION}

The relationship between competition and innovation has long been a centre of academic attention in economics literature and in the international business (IB) field. Existing research in economics literature is mainly built on two traditional views: the ‘Schumpeterian effect of competition’ which emphasizes that increased competition discourages innovation, and the 'escape competition effect' with a stress on the innovation-enhancing effect of competition. Empirical findings are mixed, with some studies reporting a positive impact of competition on innovation (Carlin et al., 2004; Nickell, 1996), while others finding a negative association (Blundell et al. 1999; Hinloopen \&

Vandekerckhove, 2009; Tang, 2006). These studies examine competition based on industry characteristics without taking account of the institutional setting of a country, which may underpin new mechanisms for the well-observed relationship between competition and innovation. For instance, unlike the free market competition in most advanced economies, a historically more coordinated market policy in transition economies such as China often shields companies, such as state-owned enterprises (SOEs), from competition. Moreover, existing research has mainly focused on examining the relationship between competition and the innovation performance of large incumbent firms (Chang \& Xu, 2008; Gorodnichenko et al., 2010; Sutton, 2007; Un, 2016). Our understanding of how private high-tech new ventures (HTNVs) in a transition economy, such as China, strive to innovate in order to compete against their rivals, and succeed in the innovation contest, remains rather limited, given their strong survivability and resilience to change (Szamosszegi \& Kyle, 2011). Thus, the relationship between competition and innovation has yet to be systematically examined in transition economy contexts.

While the economic literature does not explicitly differentiate between foreign and domestic competition, existing research on the spillover effect of foreign direct investment (FDI) in the IB literature has recognized the impact of foreign firms from developed countries on productivity and the performance of local firms in developing host countries, and has identified four main channels through which foreign firms affect local firms’ productivity and technology upgrading: demonstration, competition, linkages and employee mobility (Liu \& Buck 2007; Perri \& Peruffo, 2016; Wei \& Liu, 2006). This stream of research is built on the notion that advanced technologies and 
modern management practices possessed by foreign firms can be learned or imitated by local firms, thereby enhancing their productivity and technology upgrading (Caves, 1974; Hymer, 1960; Belderbos et al., 2015). However, empirical evidence on the spillover effect of FDI is mixed. Some studies have found a positive FDI spillover effect on domestic firms (Tian, 2007; Wei \&Liu, 2006; Zhang et al., 2014), whereas others have shown no evidence, or even a negative association between the presence of foreign firms and local firms’ productivity (Aitken \& Harrison, 1999; Feinberg \& Majumdar, 2001; Haddad \& Harrison, 1993).

The lack of sound reconciliation for these contradictory findings underlies two important gaps in the existing literature. First, most IB studies consider domestic firms as homogenous entities without taking into account different types of ownership. This may be problematic, given that variations in ownership type may create heterogeneity in firms' resource profiles and their strategic actions taken to alleviate external resource constraints. Second, the common outcome examined by these IB studies is firm performance in general. However, domestic firms' innovation, in particular the spillover effect of foreign competition on local firms' innovation, has not yet been thoroughly explored. Little attention has been paid to the role of SOEs in encouraging indigenous innovation, which may substantially decrease local firms' dependence on foreign technologies in countries such as China (Szamosszegi \& Kyle, 2011).

Our study is motivated by the need to address these gaps by differentiating the source of competition based on a multilevel analysis. Closing these gaps is of particular importance as doing so may evoke some new theoretical mechanisms that affect the known mechanisms that drive the competition-innovation relationship, in addition to its contribution to reconciling the inconsistent findings on competition and innovation. To unpack what lies behind different sources of competition and to better understand the relationship between competition and innovation in the context of a transition economy, we examine the extent to which different types of competition (foreign firms and SOEs) affect the innovation performance of private HTNVs. Adopting a resource dependence perspective, we distinguish between private HTNV-foreign firm interdependence through resource exchange and private HTNV-SOE interdependence through state ownership. We develop resource dependence logic of learning and innovation to differentiate private firms' strategic actions through 
which they can alter the patterns of these different forms of interdependencies with competitors. According to such logics, the entry of foreign rivals reduces the overall profit margins of incumbent firms, thereby diminishing or eliminating the level of slack resources that can be used by private firms for innovation (Inkpen \& Beamish, 1997). However, private firms are able to survive by minimizing their downside loss in market share through learning from and imitating their foreign counterparts (Wei et al., 2008). Thus, we argue that up to a certain level of foreign competition, the negative impact of foreign competition on innovation prevails because of the dominance of the resource dependence logic of learning. Beyond this threshold point, the resource dependence logic of innovation becomes prevalent, as private firms face the paradox of imitation choices and increasing learning costs. Therefore, the innovation-enhancing effect of foreign competition may overwhelm its negative effect. By contrast, we propose that the resource dependence logic of innovation will prevail in the face of SOE competition, as private firms can alleviate their resource dependence on SOEs and increase their relative power through a variety of innovation activities (Li \& Atuahene-Gima, 2002). This innovation-enhancing effect is more likely to hold at high levels of SOE competition because of the existence of the innovation sunk costs and the survival priorities of private firms (Park et al., 2006; Pfeffer \& Salancik, 1978).

We test these predictions using detailed data on foreign competition, SOE competition and the innovation performance of Chinese private HTNVs during the period 2001-2007. Our empirical results support our predictions and reveal fundamental differences between foreign and SOE competition with regard to their implications for the innovation performance of private HTNVs. We find a curvilinear U-shaped relationship between foreign competition and private HTNVs' innovation performance, and a positive relationship between SOE competition and private HTNVs' innovation performance.

Our study contributes to the existing literature on IB, competition and innovation, as well as resource dependence theory, in several ways. First, our study advances a context-based refinement of FDI spillovers by exclusively examining the impact of foreign competition on Chinese private HTNVs. We add a new dimension on FDI spillovers by articulating and distinguishing the 'competition effect' of FDI on private HTNVs innovation performance. Second, we offer an 
alternative theoretical rationale, supported by empirical evidence, for a more complex link between competition and innovation. Based on the resource dependency theory, we are able to specify the impact of different sources of competition on the innovation performance of private HTNVs by exploring their distinct resource interdependencies with each type of competitor. Finally, our study provides a refinement of resource dependence theory. We consider the government as a source of external dependence for SOEs and thus move beyond the dyadic interdependence between SOEs and private firms by examining the 'multiplexity' of their resource dependency relationships (Hillman et al., 2011).

\section{THEORY AND HYPOTHESES}

\section{Theoretical Background: Resource Dependence Theory}

The resource dependence theory considers external resource interdependencies as a key determinant of firms' behaviour in their resource exchange with other firms. According to this theory, organizations are both supported and constrained by their external environment and act to attempt to manage resource dependencies and counteract the power of key resource holders (Garud et al., 2002; Pfeffer \& Salancik, 2003: xxxiii). Pfeffer and Salancik (1978: 40) defined interdependence as a phenomenon that 'exists whenever one actor does not entirely control all of the conditions necessary for the achievement of an action or for obtaining the outcome desired from the action'. Such interdependencies are typically exemplified through two essential elements - mutual dependence, which represents the total dependencies between two actors, and power imbalance, which captures the difference between dependencies (Christensen \& Bower, 1996; Emerson, 1962; Gulati \& Sytch, 2007). Depending on the conditions of the external control of organizations, they can implement interorganizational arrangements, such as alliances and joint ventures, to comply with their external constraints, or even attempt to avoid or influence the constraints through inter-organizational links that help increase mutual dependence and reduce power imbalances between the focal firm and those parties in its environment on whom it depends for critical resources (Casciaro \& Piskorski, 2005;

Pfeffer \& Salancik, 1978). 
The resource dependence theory provides a solid rationale for understanding not only collaboration but also competition among firms. The emphasis on power gained through a firm's external control of resources suggests that the competitiveness of a firm can be derived from its relative power over others. The extent to which a firm can escape and/or adapt to external constraints resulting from competition is determined by the ability to simultaneously reduce its resource dependence while cultivating that of competitors in order to increase competitive power in an effective and efficient manner (Pfeffer \& Salancik, 1978). This may influence the pattern of competitive rivalry in several ways.

\section{The Resource Dependence Logic of Learning}

First and foremost, a firm can seek alternative resources by taking strategic actions to prevent its dependence concentration and increase its relative power. Learning as an adaptation strategy allows the firm to cope with external constraints by decreasing its dependence on its rivals (Peng \& Beamish, 2014). If a firm and its competitors are mutually dependent but the firm has less power over its competitors, learning to acquire and develop the rivals' resources enables the firm to minimize the influence of its dependence on the competitors and counterbalance their power in the long run. This can effectively tip the balance of power in the focal firm’s favour (Kraatz \& Zajac, 2001).

\section{The Resource Dependence Logic of Innovation}

Second, a firm can innovate to overcome or avoid external constraints, thereby altering the patterns of mutual dependence. If the critical and scarce resources required by the firm are non-substitutable, or the replacement of these resources proves costly, it can alleviate its dependence on such resources by enhancing the efficiency of its resource usage, and/or diversifying through innovation into other markets where the firm is not constrained by the dominant players in its current market (Pfeffer, 1972; 1976). In addition, a firm can cultivate and strengthen its competitors' dependence in their resource exchange relationships in order to increase its relative power, by introducing new disruptive technologies through innovation (Christensen \& Bower, 1996). However, such resource dependence is temporary, as competitors will eventually absorb the technologies and retaliate with more advanced 
innovation (Lado et al., 2006; Christensen et al., 2008). This situation often occurs when the critical and scarce resources needed by the firm are intangible and cost less to be replicated elsewhere. A cooperation strategy is typically adopted to gain access to partners' critical resources, before the firm is able to break away and become a competitor (Jorde \& Teece, 1989). It is worth noting that the above mentioned competitive actions and responses have to be tied to market demand, since customers provide the ultimate resources the firm needs to survive (Christensen \& Bower, 1996).

Based on the resource dependence logics of learning and innovation, we attempt to explain heterogeneity in the effects of foreign and SOE competition on private firms' innovation performance. We do this by considering different forms of resource interdependence and the strategic actions private new ventures take to reduce their resource dependence and power imbalance. We argue that Chinese private new ventures are able to reduce their dependence on foreign rivals through learning and imitating their advanced technologies and managerial skills, and to increase their relative power in the resource exchange through innovation (Buckley et al., 2002; Yip \& McKern, 2016; Zhang et al., 2010). Equally, by capitalizing on emerging technology areas that are out of the focus of SOEs, private new ventures effectively reduce the constraints associated with dependence on SOEs in the current market segment, and thus increase their relative power (Tan \& Peng, 2003).

\section{Limitations of the Resource Dependence Logic of Learning: The Learning Cost}

The resource dependence logic of learning, based on maintaining the control of critical resources, overlooks the strategic priorities of firms associated with the potential cost and risk of shaping the patterns of resource interdependence in their own favour. In particular, learning based rationales overstress the learning benefits private firms have which, after a certain level of foreign competition, may diminish because the cost and risk of maintaining such interdependent relationships based on resource exchange may increase faster than the benefits, and so threaten their survival.

The cost of learning will increase as certain advanced resources are often context or country specific, and can only be leveraged on a global basis. This makes it more difficult and resource intensive to absorb these resources. The lack of commonality in the prior knowledge base of companies engenders distortion and loss of information when private firms attempt to decode, 
interpret and ultimately assimilate the advanced knowledge of foreign rivals. Moreover, the greater the number of foreign firms, the higher the level of diversity of advanced critical resources private firms need to take into account. The path dependent nature of learning suggests that prior knowledge is essential to a firm's ability to absorb new knowledge (Lane \& Lubatkin, 1998). As private firms acquire knowledge from sources farther afield, it is less likely they will possess the prior knowledge necessary to fully comprehend and appropriately value the discoveries, leading to missed opportunities. This is due to the limitations firms experience with achieving sufficient knowledge diversity to value all possible discoveries (Gavetti \& Levinthal, 2000). Thus at high levels of foreign competition, the learning effect diminishes as a result of the prior knowledge limitations of private firms, making it harder for them to survive on imitation activities.

\section{Characteristics of Chinese Private High-Tech New Ventures}

Here we consider learning as a key characteristic or strategic action of Chinese private HTNVs in their attempt to reduce mutual dependence and counterbalance the power of foreign entrants. To adapt to the dynamic environment caused by the entry of foreign firms, private new ventures are compelled to utilize their learning capability to tap into the new knowledge, and develop competencies they do not currently possess. This is mainly due to the fact that most local firms lag behind their foreign counterparts (Fuller, 2006; Liu et al., 2009; Zhang et al., 2010). It is very unlikely that leveraging existing knowledge and competence will help these firms adapt to the competitive pressure and withstand the threat from foreign firms. However, private firms may create value through replicating foreign rivals’ advanced technology quickly and more cheaply. There are several ways in which private firms can catch up with their foreign rivals in innovation through learning.

First, private firms may be motivated to learn from foreign firms by imitation (Buckley et al., 2002; Zhang et al., 2010). In this case, advanced technologies and new products brought by foreign firms might serve as a learning platform for private new ventures ${ }^{1}$. These firms are more likely to follow a trajectory from duplicative imitation of technological knowledge to creative imitation of technological competence in order to move up the ladder of innovation (Boulding \& Christen, 2001; Park \& Bae, 2004; Yip \& McKern, 2016; Zhou, 2006). Noteworthy is that for private firms, the 
ultimate goal is to emulate the technological capabilities of foreign rivals, and improve their own absorptive capacity, which has long-term value to their innovation, rather than to replicate the existing knowledge/technologies of foreign counterparts, which may become obsolete rapidly (Cohen \& Levinthal, 1989) ${ }^{2}$. Thus, the presence of foreign entrants can stimulate local new ventures' innovative activities through creative imitation or by reverse engineering the outputs of foreign firms’ R\&D projects (Collinson, 2013; Liu \& Buck, 2007; Wei et al., 2008; Xie \& Wu, 2003).

Second, private firms may seek to minimize the threat of foreign rivals by collaborating with their foreign competitors and/or becoming their local contractors, which represents an opportunity for local private firms to innovate through vicarious learning (Gnyawali \& Park, 2009; Tomlinson \& Jackson, 2013; Zhao et al., 2005; Prashantham \& Dhanaraj, 2015) ${ }^{3}$. Private firms may gain the necessary skills and capabilities for innovation and a better appreciation of its commercial benefits through direct interaction with foreign pioneers, and through observing and evaluating their innovation effort and outputs (Groenendijk et al., 2013) ${ }^{4}$.

\section{Hypotheses}

\section{Foreign Competition}

The degree of foreign competition in a domestic firm's focal market is likely to influence its innovation performance. The presence of foreign firms is more likely to increase competitive rivalry since foreign firms possess both country and firm-specific capabilities that differ not only substantially from those of domestic firms, but are also critical to their operations (Kogut \& Zander, 1995; Wiersema \& Bowen, 2008). Thus an increase in the number of foreign firms in the domestic market boosts the overall competitive level and drives down the average profit margins, which significantly reduces or eliminates the slack resources available for private HTNVs to reinvest in innovation. .

Low levels of foreign competition. Instead of establishing a full and extensive business network in each country they enter, foreign firms may collaborate with local suppliers and distributors (Barlett et al., 2013; Prashantham \& Dhanaraj, 2015; Zhou et al., 2007), and exchange critical complementary resources with their local partners. Foreign entrants rely on private HTNVs for local 
knowledge and resources, to overcome their liability of foreignness and to reduce transportation and distribution costs, as well as potential local competition (Chang \& Xu, 2008; Nachum, 2010). Private firms depend on foreign firms for advanced resources, such as advanced technologies and business models. This type of exchange relationship creates a power imbalance which favours foreign firms, whose control over important advanced resources gives their products a quality advantage that can be translated into higher profits through either charging a higher price or capturing a larger market share (Chang \& Park, 2012; Prashantham \& Dhanaraj, 2015). The greater bargaining power of foreign firms is more likely to be sustained up to a certain level of foreign competition, because private firms possess neither the capability nor the slack resources to develop these critical advanced resources internally within a short period of time, and the cost of access to alternative resources is similar. To balance foreign firms’ power advantage and reduce their resource dependence, private firms may seek to exploit potential opportunities for learning through close monitoring, and then imitating the activities of rivals or partners. Empirical research shows that many Chinese private high-tech companies have gained access to the advanced technologies of their foreign counterparts through close interaction with them via the formal and informal meetings held as part of their joint R\&D projects (Wei et al., 2008; Zhao et al., 2005). These firms are then able to effectively compete with their foreign rivals by imitating their advanced technologies after making small product and process improvements (Dobson \& Safarian, 2008; Tsang, 2002; Yip \& McKern, 2016). Specifically, by imitating at a low cost, private firms effectively transfer the sunk cost of innovation to their foreign counterparts, and by operating domestically they avoid any additional costs incurred by foreign operations (Dobson \& Safarian, 2008; Engels \& Hunt, 2010).

However, given that imitation is beneficial for private firms at low levels of foreign competition, which effectively alleviates their resource dependence on their foreign counterparts, the motivation of innovation is more likely to override that of imitation for several reasons. First, the presence of a limited number of foreign rivals in the domestic market makes it harder for these firms to find an appropriate foreign firm to imitate, thereby discouraging their imitation activity. Second, to reduce or eliminate the constraints on access to, and choice of, foreign knowledge, our theoretical development suggests that private firms are more likely to avoid the learning-based interdependence 
with foreign firms through innovation. This effect, however, only holds when there are a fairly small number of foreign players in the domestic market and before they capture a large market share (Spencer, 2008), because although the overall sales of private firms may decrease as a result of foreign competition, their profit margins are sufficient to maintain their survival.

Moderate levels of foreign competition. Increasing competition from more advanced foreign products leads to diminishing demand for existing products, leaving private firms with a reduced profit margin and no slack to invest in innovation (Barringer \& Ireland, 2010; Brock \& Scheinkman, 1985). The incentives of imitation - generating slack resources and maintaining control of critical resources - as discussed above, are more likely to overwhelm those of innovation. For private new ventures with a higher risk of being crowded out of the market due to potential losses in market share, imitation is more beneficial and feasible than innovation at moderate levels of foreign competition. They can survive with their earnings from imitation (Yip \& McKern, 2016). It costs less to imitate, although the imitative products cannot be sold at a higher price than those of the foreign pioneers, as they are new to private firms but not to the market, in particular when buyers' switching costs for their products are fully exploited. It is easier for private firms to pick the most appropriate knowledge that fits well with their capabilities to imitate at this level than at the lower levels of foreign competition where there is too little foreign knowledge to choose from (Gavetti \& Levinthal, 2000). By contrast, innovation is inherently risky at this level, in particular before private firms can accumulate a sufficient level of capability and slack from their imitation sales to innovate and shoulder the risk. Moreover, access to external funding for start-up innovation is rather limited in transitional economies, such as China, compared to those in advanced economies (Ahlstrom \& Bruton, 2006; Bruton et al., 2008). Thus, picking lower hanging fruit is a less risky and more effective strategy to ensure their short-term viability.

Higher levels of foreign competition. There are at least two rationales, based on the pressures to innovate arising from the increasing costs of learning or imitation, which support the notion of a curvilinear (U-shaped) relationship. In the first rationale, the pressure to innovate increases when there is a high concentration of foreign firms in the market, and the reduced overall sales of private firms are not covering their costs (Spencer, 2008). The presence of a substantial number of foreign 
rivals not only considerably increases the total number of firms in the high-tech industries, resulting in a crowded domestic market, but also leads to a high level of market fragmentation (Katila \& Shane, 2005). Facing too many attractive options to choose from may ultimately increase the cost of imitation, since private firms have to spend a considerable amount of time and resources screening, identifying and assessing foreign knowledge or technologies that they may decide not to imitate. In addition, a highly fragmented market raises the demand for greater diversity in product offerings, which encourages private firms to innovate (Katila \& Shane, 2005; Moorman \& Miner, 1998). This implies that imitation becomes a less valuable option for private firms to follow than innovation at this stage, as the profit margins for imitated products are disappearing (Mourdoukoutas, 2015). To survive, they have to fight back to regain their lost market share through innovation. The second pressure to innovate in our second rationale is that the cost of learning will escalate up to a point where the priority of reducing the cost and risk associated with learning overrides the priority of acquiring critical resources through learning from foreign counterparts (Gavetti \& Levinthal, 2000; Leiponen \& Helfat, 2010; Szulanski, 1996). Meanwhile, for foreign rivals, imitation effectively cuts into their earnings. To regain their powerful position in the relationship with private firms, and restore their profitability and market shares, foreign firms are more likely to increase their control of the critical advanced resources required by private firms through importing new technologies that may be rooted in their unique organisational and local environments, which makes them more complex, firmspecific and difficult to duplicate elsewhere (Barney, 2001; Brandt \& Thun, 2010; Gorodnichenkoet al., 2010).

In summary, we argue that at lower and higher levels of foreign competition, the innovation enhancing effect of foreign competition is more pronounced due to the dominance of the resource dependence logic of learning and innovation. In particular, the learning cost associated with imitation at high levels of foreign competition is expected to overtake its financial returns, whereas the benefits of pursuing innovation override its potential risk. By contrast, we anticipate that at moderate levels of foreign competition, its negative effect overwhelms its positive effect on private firms' innovation performance as the resource dependence logic of learning tends to govern the interaction between 
foreign and private firms, such that the strength of learning overrides that of competing for innovation by private firms. Thus, we propose:

Hypothesis 1: The relationship between foreign competition and the innovation performance of Chinese private high-tech new ventures is a curvilinear (a U-shaped) function, with innovation performance decreasing at a moderate level of foreign competition and increasing at a high level of foreign competition.

\section{Competition from SOEs}

Although private HTNVs face competitive pressure from both SOEs and foreign firms, the impact of SOE competition on their innovation performance may vary from that of foreign competition due to SOEs’ special relationship with the government, resulting in a differing form of resource interdependence compared with foreign firms. SOEs are treated as both economic entities and government units in China. They are embedded in a strong and extensive bureaucratic network as the managers of SOEs are often former party members or governmental officials (Chang \& Xu, 2008; Xu \& Zhang, 2008). Their political status and political connections enable SOEs to gain preferential treatment in terms of resources, contracts and subsidies (Nee \& Matthews, 1996; Tian \& Estrin, 2008). Thus, the competition between SOEs and domestic private firms is influenced by government intervention and is less market-driven (Mueller et al., 2013).

SOEs have monopolies over restricted state-controlled resources, such as land and oil, that are essential for both foreign and domestic competitors to maintain their local operations. The financial system heavily favours SOEs as they are not directly subject to the scrutiny of the capital market, resulting in SOEs’ soft budgets (Bai et al., 2006; Lin \& Tan, 1999). For example, in return for guaranteed profits and state backing, official banks lend to SOEs at a third of the cost of credit available to private companies (Brandt $\& \mathrm{Li}$, 2003; The Economist, 2012). The resource profile of SOEs as a special government unit has several implications for their resource interdependence with private firms, which is different from that of foreign entrants. First, unlike foreign firms with 'temporary' control of advance resources which private firms need, SOEs 'always' pre-empt the 
critical scarce resources required for private firms' innovation activities, in particular those ‘irreplaceable’ strategic resources controlled by the state, such as transportation as part of a firm’s distribution network, as well as the water and electricity that are necessary for local operations. Thus the bargaining power of SOEs over private firms is unlikely to be altered unless private firms cultivate SOEs’ dependence by controlling those critical resources required by the SOEs. SOEs typically sell the right to use scarce resources to their rivals at a high price to ensure the price competitiveness of their own products. To sustain their survival, private HTNVs have to pay dearly for those resources, since there is hardly any alternative to such resources available. This suggests a persistently linear effect of SOE competition on private firms' innovation performance. Second, the level of mutual dependence of SOEs and private firms is much lower than that of foreign firms and private firms, because the critical resources required by foreign firms and private new ventures, such as local knowledge and advanced technologies and managerial expertise, can be acquired through learning from each other (Xia et al., 2013; Yip \& McKern, 2016; Zhang et al., 2010). Thus, their relative power advantage established through mutual dependence is more likely to be balanced. In contrast, SOEs rely on the government instead of private new ventures for critical resources. The governments in transitional economies such as China often possess significant strategic resources and usually serve as an important source of resources for SOEs (Hoskisson et al., 2000; Ma \& Delios, 2010). Private new ventures in China are typically resource constrained, and funding for innovation is rather limited as they are discriminated against in China's credit market, which is based on connections and government intervention rather than commercial considerations (Che, 2002; McMillan \& Woodruff, 2002).

Although their dependence on SOEs for the restricted state resources cannot be replaced or minimized, private firms can reduce the cost of using such resources, and/or increase the strength of resource exchanges. In doing so, private HTNVs may seek to innovate in order to use their limited resources more efficiently, which will give them a cost advantage resulting in a larger profit margin. The innate characteristics of private firms, such as agility and adaptability, further enable them to be more efficient than SOEs in exploiting the potential commercial returns arising from their innovation (Atherton \& Smallbone, 2013). The greater efficiency achieved through innovation is more likely to 
give private firms a higher profit margin than SOEs (Brandt \& Thun, 2010), which increases the level of slack resources that can be used to re-invest in innovation. The historical inefficiencies in resource allocation under the planned economy force SOEs to compete for limited inputs that will enable them to meet or exceed production targets, instead of maximizing their financial performance (White, 2000). Despite the fact that SOEs may dominate certain industries with the support of the government, their profit margin remains relatively low because of their diverse range of inefficient manufacturing activities (Peng, 2003). Their survival, to a large extent, depends on government subsidies instead of market competition (Bai et al., 2006; Hafsi \& Koenig, 1988).

In addition, private firms are able to counterbalance the power of SOEs through the control of advanced resources such as innovation. Because of their technical limitations and/or central government restrictions, SOEs typically acquire necessary inputs, such as innovation, that they are unable to produce, and internalize those inputs that they could produce regardless of obvious diseconomies of scale (White, 2000). This effectively provides private firms with the opportunity to exchange their innovation for the critical strategic resources necessary for their operations with SOEs, thereby enhancing SOEs’ resource dependence on private firms and increasing their relative power (Tan \& Peng, 2003).

According to the resource dependence theory (Pfeffer \& Salancik, 1978), the likelihood of firms using an escape or avoidance strategy increases when they have little control of critical external resources. To avoid or escape direct competition with SOEs, private firms may venture into emerging technology areas or markets within the same sector, where there is no well-established competitor, and the technologies are at an early stage of embryonic development, with a high level of risk and uncertainty. This avoidance strategy is feasible as private HTNVs are arguably much nimbler and more agile entities compared with SOEs, and thus may learn quickly to innovate in order to serve the markets untapped by SOEs (Li \& Atuahene-Gima, 2002; Yip \& McKern, 2016 ) ${ }^{5}$. SOEs are unwilling to capitalize on these risky and unproven technologies, as they are unable to obtain additional capital backing and other support from the government, whose main interest and function is to reduce uncertainty (North, 1990; Brandt \& Thun, 2010). In fact, the government support for SOEs in 
transitional economies only focuses on the development of low risk technologies, and/or areas with low technology uncertainty but high commercial viability (Yamakawa et al., 2008).

At high levels of SOE competition the incentive for private firms to innovate is more likely to hold for several reasons. First, although increased competition from SOEs may reduce the overall profit margin of innovative products, the potential significant profit loss that would arise without innovating at high levels of SOE competition is more likely to drive a private HTNV into liquidation or bankruptcy, compared to the low post-innovating profit which can at least sustain its survival. Second, the existence of the sunk cost of innovation may motivate private HTNVs to continuously race against SOEs in innovation. Empirical studies find that sunk costs lead to persistence in the patterns of Chinese firms' innovation activity (Wu, 2012; Yi \& Wang, 2012; Zhang, 2015). Before the innovation, increased SOE competition provided private firms with an incentive to innovate, therefore they incurred innovation costs, such as R\&D investment, which cannot be recouped once the money has been spent regardless of the outcome (Dixit \& Stiglitz, 1977; Salop, 1977). However, private firms can maximize future gains from their investment in these costs if they surpass SOEs in innovation with reasonable profits generated from their innovation projects. Thus, the greater the innovation sunk costs are, the more likely it is that private firms decide to complete their innovation projects. This rationale is reinforced if abolishing an innovation project proves costly, for instance when terminating the innovation project involves displacement of workers.

The above discussion implies that SOEs dominate the restricted state controlled resources that are required by private firms to survive. However, private firms can innovate to reduce their resource dependence on SOEs by enhancing the efficiency of their resource usage, and/or capitalizing on emerging technologies within the same sector where SOEs are not interested in making any investment without government-backing. This innovation incentive of private firms still holds at high levels of SOE competition due to the existence of the sunk costs of innovation and the potential threats of bankruptcy without innovating. 
Hypothesis 2: Competition from SOEs is positively associated with the innovation performance of private high-tech new ventures in China.

\section{METHODS}

\section{Data and Sample}

Our analysis of the impact of foreign and SOE competition on the innovation of private HTNVs in China is based on data taken from the Annual Census of Industrial Firms, administered by the Chinese National Bureau of Statistics (NBS). The dataset covers all domestic and foreign firms operating in China with annual sales of at least 5 million RMB (approximately US\$676,000). It contains detailed information on the key financial indicators, i.e. turnover, R\&D, new product development, exporting, etc. at both firm and industry levels. The dataset is considered as the most appropriate for the purpose of our study for a number of reasons. First, it is the most comprehensive and widely used dataset for the study of Chinese firms (e.g. Chang \& Xu, 2008; Liu et al., 2009; Pan et al., 1999; Park et al., 2006). The high degree of accuracy and internal consistency of the data makes this dataset ideal for empirical analysis (Chow, 1993). Second, compared to cross-sectional data, the longitudinal census data allow us to better capture the dynamic competition and firm innovation activities over time, as well as their causal relationships, by applying a multidimensional panel structure (Baltagi, 2008).

We focus on the 2001-2007 period in particular. Since China joined the WTO in 2001, market access for foreign firms has been significantly enhanced with many restrictions on foreign operations being lifted. In the meantime, SOEs have gone through major reforms. These structural changes have dramatically intensified the competition within the domestic market, evidenced by the growing sales of foreign firms and SOEs in the subsequent years (Chang \& Xu, 2008; Liu \& Buck, 2007). We choose 2007 as our cutoff point to exclude the impact of the global financial crisis and policy changes (Haveman et al., 2016). The year 2007 saw a tipping point for increased inward FDI activity in China before 2008, when the number of foreign firms operating in China plunged dramatically (CCPIT, 2009). This was due partly to the global financial crisis, which resulted in the bankruptcy of many major foreign players at the time, and the introduction of 'integrated income tax', which removed the 
tax incentive for foreign firms for the first time, leading to the exit of some weak foreign players from China because of reduced profit margins (Brean, 2008; CCPIT, 2009). Thus, the sample period allows us to capture how different types of competitive forces shape the innovation performance of private new ventures in the context of economic transition.

We consider the Chinese high-tech sector as the most appropriate setting for our research, as past studies have emphasized the threat and/or importance of foreign entrants on the innovativeness of domestic Chinese high-tech firms, given the costly and risky nature of the innovation process in these high-tech firms (Pisano, 1990; Wei \&Liu, 2006; Zhang et al., 2014). We use the OECD classification of the high-tech sector adopted by China, which defines high-tech industries as industries with a higher OECD-average direct, indirect and overall R\&D intensity (i.e. greater than 9.33\%) than those in a lower category over the 1980-1990 period (Hatzichronoglou,1997). We focus on domestic private HTNVs, defined as Chinese private high-tech firms that are less than 10 years old with fewer than 500 employees and annual sales of no more than 30 million Chinese RMB in 2001(Zhou et al., 2007), as it usually takes 10 years for a high-tech company, in particular a pharmaceutical firm, to bring a new drug from discovery to FDA approval - a time horizon that captures the transition from a new venture to an established business (Certo et al., 2001; Covin \& Slevin, 1990; Shepherd, 1999). According to the statistics provided by the China National Bureau of Statistics, around 65 per cent of patent applications and about 60 per cent of products that are new in the market are from domestic private high-tech start-ups. We reviewed the demographic profile of each firm in the dataset, including ownership structure, establishment year, size and standard industry classification code (SIC) ${ }^{6}$ and verified its inclusion in our final sample of domestic private HTNVs. We excluded firms without any sales of newly commercialized products over the seven-year period, as these firms either did not possess an innovation oriented business model, or stayed dormant for various reasons (Storey \& Greene, 2010). The resulting dataset comprises 805 small and medium-sized domestic high-tech new ventures, with a total of 5,635 observations over a seven-year period. These firms cover four major three-digit Chinese standard industrial classification code (SIC) manufacturing industries included in the Chinese Statistic Yearbook, i.e. radio, TV and communications equipment industry (401-3, 4059), the pharmaceutical industry (271-6), the office, accounting and computing machinery industry 
(404, 415) and the medical, precision and optical instruments industry (368, 411-2, 419, 414). We excluded the aircraft and spacecraft industry in which there is little information on foreign and private firms due mainly to two reasons. First, the aerospace industry is one of China's designated strategic emerging industries, which restricts non-Chinese ownership and requires the use of joint ventures with local firms as the only entry mode for foreign firms. Second, the industry is composed of mostly SOEs with a very limited number of private firms. To avoid endogeneity problems and establish causal relationships, we lagged all independent variables by one year $(t-1)$. This allowed us to create a panel with 4,830 observations (805 X 6) for model estimation.

\section{Dependent Variable}

We measure innovation performance by the NBS' indicator - percentage of annual sales generated by products that are 'new' to the market (Cassiman \& Veulegers, 2002; He \& Wong, 2004). New product sales are commonly considered to be an appropriate indicator of the commercial success of a firm's innovation activity (Atuahene-Gima \& Li, 2004; Autio et al., 2000). This measure allows us to capture the performance dimensions that have been undervalued by other innovation performance measurements, such as patent count. Chinese firms have an incentive to record new product sales since governmental approval of new products attracts tax subsidies from the provincial or central government. In contrast to the standard definition of a new product, which defines it as either a novel or an improved product (SSB, 2003), the concept of a new product in this context is more specific the quality and/or function of the existing product should have undergone a significant improvement through the adoption of a new structure, material or manufacturing technique.

\section{Independent Variables}

Foreign and SOE competition is measured using the Herfindahl Index (HHI), which is the sum of the squares of the market share of total foreign invested enterprises (FIEs) and total SOEs in each hightech sector, respectively. The measure is specified as follows:

$$
\text { Herfindehl Index }(\mathrm{HHI})=\quad+\quad+\quad+\ldots+
$$


Where $S_{i}$ is the market share of $i^{\text {th }}$ firm. $i=1,2,3, \ldots$ m. The lower the value of the Herfindahl Index, the higher the level of foreign or domestic competition. We used the inverse measure (1/HHI) such that a greater value indicates a higher level of foreign or SOE competition (Bowen \& Wiersema, 2005; Zhang et al., 2010).We extracted relevant information on the market share of FIEs and SOEs at the industry level from the Chinese Statistic Yearbooks on High-Tech Industries (2001-2007). The variables allow us to capture changes in market structure which are reflected in the intensity of each type of competition (Acs \& Audretsch, 1998; Nickell, 1996). As an alternative measurement, we used the concentration ratio to proxy foreign and SOE competition. This is calculated as the sum of the market shares of the four largest foreign firms or SOEs within each high-tech sector. This alternative measure produced results consistent with those reported in Table $3^{7}$.

In addition, we controlled for innovation effort, commercial effort, firm age, size, sector, location, export intensity, foreign $R \& D$ spillover and capital intensity. A private new venture’s innovation effort is operationalized by its $\mathrm{R} \& \mathrm{D}$ intensity, which is defined as $\mathrm{R} \& \mathrm{D}$ expenditure relative to total sales. This measure is widely used as a standard measurement for a firm's innovation input (Cassiman \& Veugelers, 2006; Cohen \& Levinthal, 1989). We measured a private new venture’s commercial effort as annual advertising expenditure divided by sales (Audretsch, 1995; Kotabe et al., 2002). Engagement with commercialization activities, such as advertising and product promotion, allows private firms to better serve the local demand and outperform their competitors in the local market. We measured firm age in years and size by number of full-time employees. Small start-up firms are usually better at innovation than large established firms due to their behavioural advantage (Katila \& Shane, 2005).To account for sectoral variations, we included a set of sector dummies which take the value of 1 if a private HTNV competes in an industry which belongs to one of the four threedigit major industries included by the Chinese Statistic Yearbook (i.e. the radio, TV and communications equipment industry, the pharmaceutical industry, the office, accounting and computing machinery industry, and the medical, precision and optical instrument industry) and 0 otherwise. We also controlled for location dummies at province level. To further capture the locational effect on innovation, we introduced three province-level institutional indexes based on the Chinese National Economic Research Institute (NERI)’s marketization indices: the level of local 
government support for innovation, the development of the market-based economy, and the development of the private sector (Fan et al., 2009). Ample empirical evidence from studies on economic history suggests that an innovation-friendly environment requires government support in many ways (Jones, 2001; North \& Thomas, 1997). Private sector is the engine of innovation (Nordhaus, 2004). The development of market-based economies increases the level of environmental uncertainty, which gives private new ventures an opportunity to disrupt the status quo and destroy the competitive advantage of more established firms through innovation (D’Aveni, 1994). Export intensity is operationalized as the total exports to sales ratio at firm level, a standard measure in the international business literature. A firm's innovation could be affected by its linkage with global markets (Escribano et al., 2009). The foreign $R \& D$ spillover effect is captured by the $R \& D$ expenditure of foreign firms as a percentage of total sales of an industry (Audretsch \& Feldman, 1996; Liu \& Buck, 2007). Prior studies show that knowledge spillovers between foreign and domestic firms can contribute to the productivity and efficiency of domestic firms (Greenaway et al., 2002; Zhang et al., 2010). We control for capital intensity by a firm's fixed asset per employee. It is likely that firms with strong capital intensity have relatively higher employee productivity and can innovate faster and more efficiently than low capital intensive firms (Deakins \& Freel, 2009).

Table 1 reports the descriptive statistics and correlations of the variables used in our analysis. Table 2 presents the descriptive statistics of our sample firms by industry. We further weighed our final sample of private HTNVs in each industry according to their distributions in our original sampling frame as Figure 1 illustrates. On average, the sample firms were 7.22 years old with 143 employees and 19 per cent of their annual sales were generated from commercialized products that are 'new' to the market only. Overall, they faced more intense competition from foreign entrants than domestic SOEs during the sample period. These private firms had a rather balanced focus on R\&D and commercial exploitation with an average spending of 21 per cent of total annual sales on each type of activity. They actively engaged in exporting activities, which brought about 18 per cent of their annual sales. 


\section{Analytical Approach}

We adopted a multilevel mixed linear model to address unobserved heterogeneity in the impact of foreign and domestic competition on the innovation performance of domestic private HTNVs due to the cross-province and cross-industry nature of our dataset. This mixed model allows us to take account of the fact that our dataset has a hierarchical structure in which individual firms represent level one, provinces represent level two and industries represent level three. In doing so, we are able to control for clustering of the data first within an industry and second within a province. To determine whether the choice of multilevel modelling with province and industry effects is appropriate, we performed a variance analysis. First, we conducted a one-way analysis of variance. The results show significant differences in the proportion of intra-group variance among firms in different provinces and industries $(\mathrm{p}<0.001)$. Second, we found that the residual variances at levels two and three in the random intercept model with all variables are statistically significant $(\mathrm{p}<0.01)$, which justifies the use of multilevel modelling.

\section{RESULTS}

Table 3 presents the results from our regression analysis of new venture innovation performance. Models 1 and 2 contain firm and industry level control variables, and subsequent models add the main variables (Models 3, 4, and 5). We conducted Wald tests on the significance of the inclusion of the independent variables in each model. The results further confirm that the inclusion of these variables significantly improves the fit of each model. In terms of variables of interest, we find a U-shaped relationship between foreign competition and private new ventures' innovation performance measured by new product sales. The result from Model 5 suggests that the innovation performance of private new ventures is negatively related to the linear term of foreign competition $(-0.323, \mathrm{p}<0.01)$, but positively related to its squared term $(0.013, \mathrm{p}<0.01)$. A test of the joint significance of linear and 
squared terms of foreign competition is statistically significant, providing strong support for Hypothesis 1. The U-shaped effect of foreign competition on private firms' innovation performance is shown in Figure 2 with 95 per cent confidence intervals. Figure 2 shows that higher innovation performance gains from increased foreign competition may be realized after the percentage of new product sales plunges to its lowest level, as indicated by the inflection point of 23.7 per cent of new product sales, at 11.8 level of foreign competition. In other words, when the level of foreign competition is greater than 11.8, its positive effects overtake its negative effects on private firms' innovation performance. Our sample mean of foreign competition (12.6) is located to the right of the minimum point (Figure 2) of 11.8, suggesting that most observations of foreign competition in our sample had a positive effect on private firms' innovation performance. In line with Hypothesis 2, we also find a significant and positive relationship between SOE competition and a private firm's innovation $(0.008, \mathrm{p}<0.001)$ in Model 5 (Table 3), suggesting that increasing competition from SOEs has a significant and positive impact on private high-tech new ventures’ innovation performance.

Insert Figure 2 about here

To investigate the economic significance of our estimates, we calculated Cohen's $f^{2}$ values for each type of competition in Model 5. Cohen's $f^{2}$ is the most commonly used, very informative, and standardized measure of effect size for analyses such as multilevel/hierarchical linear modelling and mixed-effects regression modelling (Selya et al., 2012). Our results show that SOE competition $\left(f^{2}=0.035\right)$ has a slightly greater impact on private high-tech new venture's innovation performance than foreign competition $\left(f^{2}=0.03\right)$ although both have moderate effect sizes which fall between the conventional cut-off points of small $\left(f^{2}=0.02\right)$ and medium $\left(f^{2}=0.15\right)$ effect sizes recommended by Cohen (1988). These results confirm that the impacts of each type of competition on private firms' innovation performance have both statistical and economic significance.

\section{Robustness Checks}


To verify the robustness of our results, we conducted several sensitivity analyses. First, we reestimated our models using a generalized linear latent and mixed model (GLM). The results from the analysis show very similar patterns - the significance level and the direction of the coefficient of each independent variable are consistent with our results. Second, in order to minimize the potential multicollinearity, we mean centred the independent variables (Aiken \& West, 1991).We also examined the variance inflation factors (VIFs) of each model after our regression analysis. All of the VIF scores are below 10, the commonly used rule of thumb for multicollinearity. Thus, our analyses are unlikely to have a serious problem with multicollinearity (Cohen et al., 2003). Third, we performed two separate estimations of our models by lagging the dependent variables for one year only and using the current values of all variables. Consistent results were obtained across our analysis of these different lag variables and lag periods ( $t$ and $t-1)$. Finally, to check for the influential points, we calculated the Cook's distance for each observation. The largest Cook's distance value is 0.04 which is less than the conventional cut-off value of 1 . Thus, the influence of this point is not great enough to be a concern.

Insert Table 3 about here

\section{Supplemental Analysis}

Competition from foreign rivals may challenge the leadership position of SOEs through market-based forces as the entry of foreign firms, to a great extent, may reduce the degree of market distortion caused by indirect government intervention. Equally, increased SOE competition slows down the process of economic transition and constrains the rational flow of resources and the market (Bai et al., 2006). In this regard, the monopoly of restricted state resources by SOEs alleviates the resource dependence of foreign firms on private new ventures because of scarce resources. In particular, those strategic resources important for local operations needed by both types of firms, are not in each other's control. Thus it is likely that the effect of SOE/foreign competition may overwhelm that of the other. To address this temporal aspect (Jia \& Mayer, 2017), we performed a supplemental test. 
As APPENDIX A shows, the coefficient of the interaction term with the linear effect of foreign competition is significant and positive $(0.062, \mathrm{p}<0.05)$. The coefficient of the interaction term with the quadratic effect of foreign competition is significant and negative $(-0.002, \mathrm{p}<0.05)$. Our additional analysis suggests that SOE competition counteracts the impact of foreign competition on private new ventures' innovation performance. Thus, a low level of SOE competition amplifies the Ushaped relationship between foreign competition and private firms' innovation performance, whereas a high level of SOE competition dampens this relationship. To illustrate this interaction effect, we plotted the significant results obtained in APPENDIX A and their 95 per cent confidence intervals in APPENDIX B. APPENDIX B shows the steeper upslope and downslope of the U-shaped curve for SOE competition at a sample minimum level of 7.2 vs the flatter upslope and downslope of the Ushaped for SOE competition at a sample maximum level of 14.7. This is consistent with our prediction that with increasing SOE competition, both the negative and positive effects of foreign competition are weakened.

\section{DISCUSSION}

This paper systematically examines the extent to which private new ventures’ innovation performance is affected by foreign and SOE competition in a transition economy. Our results suggest that the relationship between competition and innovation is not universal but is subject to the level and source of competition, which determines the resource dependence of the focal firm and its competitors. The dynamics of such relationships are made further evident by a curvilinear U-shaped relationship between foreign competition and the innovation performance of private HTNVs. While the findings are consistent with the previous literature which suggests that the entry of foreign firms represents an opportunity for private HTNVs to learn from these firms (Liu \& Wang, 2003; Wei \& Liu, 2006; Zhang et al., 2010), our detailed analysis also shows that the innovation performance of private HTNVs varies with the degree of foreign competition: private HTNVs can undercut foreign competition through learning to move up the ladder of innovation at moderate levels of foreign competition, but there is a trade-off between learning costs and benefits at higher levels foreign 
competition and a lack of imitation choices at a low level of foreign competition. In contrast, we find that SOE competition has a positive association with local private firms' innovation performance. This finding may reflect the fact that private firms consider innovation as a strategic means of balancing their resource dependence on SOEs. It represents a viable way through which private firms outcompete SOEs by enhancing the efficiency of their resource usage and/or capitalizing on emerging technological areas within the same sector where SOEs also compete.

\section{Contributions to the Literature on International Business}

Our study complements existing knowledge on the competition mechanism of the FDI spillovers effect on transition economy firms in several distinctive ways. First, our study advances a contextually based understanding of foreign competition. Existing theories on FDI spillovers are mainly built on the performance gains of local firms from the presence of foreign players in general (Altomonte \& Pennings, 2009; Gorg \& Strobl, 2001; Haskel et al., 2007). Such a generic treatment of 'local firms’ obscures variations in firms’ responses to foreign competition driven by different resource dependence logics associated with their specific ownership type and institutional context, such as transition economies, where market forces are not fully established and government intervention is still prevalent. Private HTNVs operating in such institutional contexts typically have greater flexibility and learning capabilities enabling them to either benefit from or adapt to foreign competition, as they are more resilient to constant shocks and changes in the external environment as a result of institution transition (Szamosszegi \& Kyle, 2011). In addition to the inadequate theoretical focus, the empirical analyses these theories rest on are often based on incomplete datasets omitting this type of firms, given the difficulty of collecting information on these firms in a transition economy setting (Eapen, 2013). Thus, existing studies may either overestimate or underestimate the effect of foreign competition without taking account of heterogeneity in local firms. Our study addresses this gap by examining the dynamic resource interdependency between private HTNVs and foreign entrants at varying levels of foreign competition to specify its impact on the innovation performance of Chinese private HTNVs. 
Second, previous FDI studies fail to make a clear distinction between the impacts of FDI and foreign competition on local firms’ productivity or innovation (Aitken \& Harrison, 1999; Tian, 2007; Wei \& Liu, 2006). These studies typically consider increased competition accompanied FDI entry as an important mechanism to explain the FDI spillover effect on local firms' productivity (Blomström \& Kokko, 1998; Chang \& Xu, 2008). This mechanism, however, has been rarely tested empirically with most FDI studies examining the crude effect of direct foreign 'input' such as quantity, shares of ownership, origin and diversity of FDI on the activity of transition economy firms, but drawing ambiguous inferences on foreign competition based on their findings (Aitken \& Harrison, 1999; Chang \& Xu, 2008; Zhang et al., 2010). Our study complements existing FDI studies by articulating the 'competition effect' of FDI entry, thus providing a more complete picture of the FDI spillover effect by introducing the resource dependence logic of innovation and learning. In particular, we are able to underpin the conditions under which foreign competition is beneficial or detrimental to private firms’ innovation performance.

\section{Contributions to the Literature on Competition and Innovation}

For the competition and innovation literature, our study reconciles previous positive (Nickell, 1996; Buckley et al., 2002; Liu \& Buck, 2007) and negative (Schumpeter, 1950; Hinloopen \& Vandekerckhove, 2009; Chang \& Xu, 2008) assertions in the literature on the relationship between foreign competition and innovation, by providing theoretical arguments and empirical evidence for a curvilinear U-shaped relationship. In contrast to the well-established linear or inverted U-shaped relationships between competition and innovation found in existing studies of advanced economies (Aghion et al., 2005; De Bondt \& Vandekerckhove, 2012; Polder \& Veldhuizen, 2012), our study’s unique focus on transition economies, and evidence of a curvilinear U-shaped relationship, implicitly highlight the importance of external resource environments and learning in shaping the relationship between competition and innovation.

Differentiating competition with foreign firms versus SOEs also enables us to evoke several new mechanisms that affect the known mechanisms that drove the inverted U-shape in the competition and innovation literature. Aghion et al. (2005) argue that at a high level of competition, if 
one firm has managed to innovate and escape competition, another firm will, in general, not find it worthwhile to catch up due to low post-innovation rent. Our prediction and findings of a constant positive effect of SOE competition on private firms' innovation performance provide both theoretical and empirical support for the argument that at high levels of competition the existence of the sunk cost of innovation further motivates private firms to engage in innovation activities, which contradicts the established negative effect of high competition on innovation (Schumpeter, 1950; Aghion et al., 2005). Another new mechanism arising from our analysis is that at high levels of SOE competition, the pressure to survive outweighs that to thrive, thus the low post-innovating profits are of less concern for private firms than the potentially significant profit losses without innovating, which could drive these firms into liquidation or bankruptcy. In addition, Aghion et al. (2005) proposed and tested the inverted U-shaped relationship in the leading firms, but not for the laggard firms. By contrast, we examine the impact of foreign competition on private HTNVs, which are apparently the laggards to foreign firms at their initial market entry. Therefore, we fill the gap in extant literature on competition and innovation by offering a perspective of laggard firms, and call for more research on this underexplored phenomenon.

\section{Contributions to Resource Dependence Theory}

Our study makes three important contributions to the extension and refinements of resource dependence theory. First, we are among the first to apply the resource dependence logic to examine competition, thus expanding the boundaries of resource dependence theory. While previous studies apply resource dependence theory to explain firms’ collaborative behaviour (Li \& Atuahene-Gima, 2002; Xia et al., 2014), we have set out to examine different types of competition through the lens of resource dependence theory. In doing so, we shed new light on two important underlying mechanisms represented by competition - firms' external resource constraints or control, and their ability to simultaneously minimize their resource dependence and maximize their external resource control (to increase their power relative to the competitors) - that affect firms' innovation. Moreover, we show that resource dependence theory can serve as a helpful exploration tool for probing and better 
understanding how heterogeneity in these two underlying mechanisms associated with different types of competition, leads to variations in innovation performance.

Second, one of the fundamental assumptions of resource dependence theory concerns the role of dependencies. However, the government as a widely recognized source of external dependence (North, 1990) has not been explored in relation to the source of competition in prior studies (Xia et al., 2014). Our study shows that the interaction of interdependent organizations and their institutional environment is a dynamic and complex process which can affect innovation outcomes. The findings reflect the fact that under incomplete economic transition accompanied by a socialist political system, the Chinese government still maintains control of the economy through less direct but more strategic participation in economic activities (Mirowski \& Plehwe, 2009). Our study thus provides a refinement of resource dependence theory by elaborating the context within which the mutual dependence and power imbalance between SOEs and private new ventures are established and highlights innovation as the only way through which private firms can survive SOE competition.

Finally, we offer a theoretical advancement of resource dependence theory by conceptualizing learning derived from foreign competition as an important strategy for private firms to alter the two underlying mechanisms - mutual dependence and power imbalance - elucidated by the resource dependence theory. This effectively addresses the shortage of studies exploring actions firms can take to manage/reduce environmental dependencies other than those originally identified by Pfeffer and Salancik (1978), such as political actions and executive succession. Exploring the scope of this learning rationale also enhances the precision of resource dependence theory in predicting firms' innovation activity, because such learning carries less imminent implications for innovation performance compared with other strategies designed to reduce dependence and/or increase power, such as looking for alternative resources and diversification into other markets which either require no innovation or have to involve innovation at the very beginning (Pfeffer \& Salancik, 1978).

\section{Policy Implications}


Our findings have important policy implications. When thinking about stimulating innovation through foreign competition, it is reasonable to assume an overall positive effect, as the negative effect is largely overlooked by existing empirical studies. However, it is important to consider the pace at which such competition is introduced. Our study suggests that exposure to extensive competition at an early stage may encourage private high-tech firms’ innovation activity but hinder their learning from foreign rivals. Policy measures should be designed to introduce foreign competition at a relatively even or slow pace in high-tech industries. In addition, for some interorganizational activities such as innovation to take place, it requires a network of complex links and feedback mechanisms, in particular those interorganizational and extraorganizational communication paths, linking the various in-house functions and allowing the firm to articulate with both the market and the wider scientific and technological community (Rothewell \& Zegveld, 1985). This will prolong the period in which private firms can catch up and/or even overtake their foreign counterparts in the innovation contest, so that these firms are able to benefit from the introduction of such competition before the market saturates.

\section{Limitations and Future Research}

As in all studies, ours has some limitations which point to future research. First, our analysis is limited to high-tech industries in a transition economy. Before being confident about any generalization, more studies should be undertaken to generalize our findings to different sectors and institutional contexts, specifically those sectors with less government intervention, and economies where the technology gap between domestic and foreign firms is negligible. Second, the causal mechanism of the non-linear relationship between foreign competition and innovation is obtained at the aggregated level over a seven-year period. More in-depth qualitative studies of the process by which private firms interact with foreign entrants and respond to their competitive threats are clearly needed in order to explore the behaviour foundation and implications of such a relationship. Additionally, a few scholars have examined how SMEs in emerging markets, such as India, learnt from large multinational firms, and the process was vividly described as 'learning to dance with gorillas' or 'swimming with sharks' (Prashantham \& Birkinshaw, 2008; Prashantham \& Dhanaraj, 2015). However, foreign competition 
may also emanate from smaller foreign companies. Thus, a fruitful future research direction would be to compare and contrast how foreign firms affect the learning process of domestic SMEs based on their size. Third, it is likely that private firms may deliberately overstate their sales generated from new products to attract government subsidies, in particular in China where private firms are not obliged to disclose any financial information in the public domain, and the enforcement of accounting rules and regulations is relatively weak compared to that in advanced economies. However, we are unable to identify this incentive from these firms directly, assuming they will not voluntarily selfdisclose their violations of company laws and generally accepted accounting principles. Future research should capture innovation performance using measurements alternative to new product sales. Fourth, our study is based on data over the period 2001-2007. However, increased development of private risk capital in China in recent years has encouraged foreign and local private entrepreneurs to seek private equity investment to fund their innovation activities. This is more likely to strengthen the positive impact of SOE competition on private firms' innovation outcome, but may have little influence on the negative moderating effect of SOE competition on the relationship between foreign competition and private firms' innovation performance. A possible reason is that even with the support of private risk capital, private new ventures are still unable to acquire the critical resources controlled by SOEs, which are 'irreplaceable' strategic resources owned by the state, such as transportation as part of a firm's distribution network, and utility supply that are necessary for local operations. In the case of foreign competition, the availability of private risk capital serves as an alternative source of resources for private new ventures to fund either their own innovation activity, or the external acquisition of advanced technological and managerial knowledge. This may reduce private firms' resource dependence on their foreign counterparts (Bruton \& Ahlstrom, 2003). Future research should test this proposition by examining the moderating effect of private risk capital on our hypothesized relationship between each type of competition and the innovation performance of private new ventures in China. Finally, while our study distinguishes the types of competitors that influence private firms' innovation differently, this difference is likely to reside in the heterogeneity in the types of innovation that different competitors trigger private firms to engage in. For instance, weaker foreign competition may result in more imitation but less novel innovation by private firms 
than stronger foreign competition, and vice versa. Given the limitation of our data, we are unable to capture the variations in the type of innovation that occurs in the presence of different levels and sources of competition. However, we have performed a supplemental analysis using number of patents at industry level as an indicator of novel innovation, with the same set of independent variables, but estimated at industry level. The results confirm our main findings and are even stronger at industry level (APPENDIX C). Future studies should go beyond examining the changes to the overall level of innovation by further distinguishing the types of innovation developed by local private firms in the face of competition from foreign firms and SOEs.

\section{CONCLUSION}

This study advances our understanding of heterogeneity in the relationship between foreign competition, SOE competition and innovation. Based on the resource dependence logics of learning and innovation under competition, we are able to unpack the dynamic intricacy of competition and innovation across different settings. By examining longitudinal data drawn from a sample of Chinese private HTNVs over the 2001-2007 period, our analysis shows that the impact of competition on innovation is contextually based, varying with the source of competition, which determines the external resource environment faced by each competitor. Specifically, our study suggests a U-shaped relationship between foreign competition and innovation performance, and a positive relationship between SOE competition and the innovation performance of private HTNVs. Our study highlights the importance of differentiating the impact of different types of competition and provides new insights into foreign and SOE competition in a transition economy.

\section{NOTES}

${ }^{1}$ Several commonly adopted learning methods have been revealed by prior studies based on qualitative analysis of how learning occurs in local Chinese firms in the presence of foreign entrants (Collinson, 2013; Wei et al., 2008; Xie \& Wu, 2003; Zhao et al., 2005). For instance, once Chinese firms have noted the advanced technologies and equipment used by foreign counterparts, they tend to 
reverse engineer the technologies. In the case of new business models bought by foreign rivals, Chinese companies typically acquire, assess and apply it with modifications according to their local market conditions. Another channel is international and domestic industrial trade fairs and exhibitions. Local companies often attend such events for the purpose of identifying new business models and learning new technological applications and new material utilization (Wei et al., 2008).

${ }^{2}$ In doing so, private firms may build their new technologies or products based on ideas or rationales inspired by high-end foreign products, and/or the enhancement of existing technologies and products introduced by foreign rivals (Kale \& Little, 2007). This is evidenced by the fast growing 'Shanzai' phenomena in a number of emerging high-tech industries; for example, in the cell phone sector where China has now become a leading global producer by replicating and innovatively imitating the technologies of advanced foreign partners (Engels \& Hunt, 2010).

${ }^{3}$ For example, Wei et al. (2008)'s study found that some Chinese private high-tech companies initially acquired the technologies of their foreign partners through the arrangement of OEMs, then used the advanced technologies they learned to target the domestic market. Equally, foreign entrants are more willing to partner with these private HTNVs to overcome their liability of foreignness and establish an effective local presence as well as to reduce potential local competition (Chang \& Xu, 2008; Nachum, 2010). Williamson and Yin (2014) have noted that two Chinese firms partnering with a foreign high-tech start-up have gained access to its advanced technology and in turn they helped the foreign company to tap into the Chinese market.

${ }^{4}$ This is evidenced by their joint R\&D projects with foreign firms through which local firms can receive direct training from foreign firms or have close interaction with them via formal and informal meetings as a way of acquiring needed advanced technologies (Zhao et al., 2005; Wei et al., 2008). Similarly, Collinson (2013) characterizes Chinese firms’ cumulative learning as a process from learning disembodied knowledge to accumulating value-adding capabilities. This process involves training and mentoring as well as learning 'by-doing' or 'on-the-job' through interaction with and/or imitation of foreign firms.

${ }^{5}$ Yip \& Mckern (2016) provide an interesting example that supports our argument here. Yuwell has grown from a township and village enterprise into an innovative medium-size company 
with over 100 patents. This success as its founder stresses, has been largely built on the premise of innovation by spotting and serving a new market niche untapped by SOEs via developing new medical devices.

${ }^{6} \mathrm{We}$ used the three-digit standard industrial classification codes of 'high-tech sectors' published by the Chinese National Bureau of Statistics. The 'high-technology' category as defined by the Chinese statistic Year Book includes the following industries: Aircraft and spacecraft; Pharmaceuticals; Office, accounting and computing machinery; Radio, TV and communications equipment; Medical, precision and optical instruments. The definition derives from the OECD definition.

${ }^{7}$ The results are not reported due to space constraints, but available upon request.

\section{ACKNOWLEDGEMENTS}

The authors are grateful to Editor-in Chief, Professor Alain Verbeke, Area Editor, Professor Jaeyong Song and three anonymous reviewers for their valuable comments. 


\section{REFERENCES}

Acs, Z. J., \& Audretsch, D. B. 1998. Innovation in large and small firms: an empirical analysis. The American Economic Review, 78: 678-690.

Aghion, P., Bloom, N., Blundell, R., Griffith, R., \& Howitt, P. 2005. Competition and innovation: an inverted-U relationship. Quarterly Journal of Economics, 120: 701-728.

Aghion, P., Blundell, R., Griffith, R., Howitt, P., \& Prantl, S. 2009. The effects of entry on incumbent innovation and productivity. The Review of Economics \& Statistics, 91: 20-32.

Aghion, P., Harris, C., Howitt, P., \& Vickers, J. 2001. Competition, Imitation and Growth with Stepby-Step Innovation. Review of Economic Studies, 68: 467-492.

Ahlstrom, D., \& Bruton, G. D. 2006. Venture capital in emerging economies: Networks and institutional change. Entrepreneurship Theory and Practice, 30(2): 299-320.

Aiken, L. S., \& West, S. G. 1991. Multiple Regression: Testing and Interpreting Interactions. London: Sage.

Altomonte, C., \& Pennings, E. 2009. Domestic plant productivity and incremental spillovers from foreign direct investment. Journal of International Business Studies, 40(7): 1131-1148.

Aitken, B, J., \& Harrison, A. E. 1999. Do domestic firms benefit from direct foreign investment? Evidence from Venezuela. American Economic Review, 89: 605-618.

Atuahene-Gima, K., \& Li, H. 2004. Strategic decision comprehensiveness and new product development outcomes in new technology ventures. Academy of Management Journal, 47: 583-597.

Atherton, A., \& Smallbone, D. 2013. Promoting private sector development in China: the challenge of building institutional capacity at the local level. Environment and Planning C: Government and Policy, 31: 5 - 23.

Audretsch, D.B. 1995. Innovation and Industry Evolution. Cambridge: MIT Press.

Audretsch, D.B., \& Feldman, M. 1996. R\&D spillovers and the geography of innovation and Production. American Economic Review, 86(3): 630-640.

Autio, E., Sapienza, H. J., \& Almeida, J. G. 2000. Effects of age at entry, knowledge intensity, and 
imitability on international growth. Academy of Management Journal, 43: 909-924.

Bai, C., Lu, J., \& Tao, Z. 2006. The multitask theory of state enterprise reform: empirical evidence from China. American Economic Review, 96(2): 353-357.

Baltagi, B. 2008. Econometric analysis of panel data. Chichester: Wiley.

Barney, J. B. 1991. Firm resources and sustained competitive advantage. Journal of Management, 17: 99-120.

Barringer, B. R., \& Ireland, R. D. 2008. Entrepreneurship: Successfully launching new ventures. New Jersey: Pearson Prentice Hall.

Belderbos, R., Lokshin, B., \& Sadowski, B. 2015. The returns to foreign R\&D. Journal of International Business Studies, 46(4): 491-504.Blomström, M., \& Kokko, A. 1998. Multinational corporations and spillovers. Journal of Economic Surveys, 12(3): 247-277.

Blundell, R., Griffith, R., \& Reenen, J. 1999. Market share, market value and innovation in a panel of British manufacturing firms. Review of Economic Studies, 66(3): 529-554.

Boulding W., \& Christen, M. 2001. First-mover disadvantage. Harvard Business Review, 79: 20-21.

Bowen, H. P., \& Wiersema, M. F. 2005. Foreign-based competition and corporate diversification strategy. Strategic Management Journal, 26(12): 1153-1171.Bowman, D., \& Gatignon, H. 1996. Order of entry as a moderator of the effect of the marketing mix on market share. Marketing Science, 5: 222-242.

Brandt, L., \& Thun, E. 2010. The fight for the middle: upgrading, competition, and industrial development in China. World Development, 38: 1555-1574.

Brandt, L., \& Li, H., 2003. Bank discrimination in transition economies: ideology, information or incentives? Journal of Comparative Economics, 31(3): 387-413.

Brean, D. J. S. 2008. Taxation in Modern China. New York: Routledge.

Brock, W. A., \& Scheinkman, J. A. 1985. Price setting supergames with capacity constraints. Review of Economic Studies, 52: 371-382.

Bruton, G. D., \& Ahlstrom, D. 2003. An institutional view of China's venture capital industry: Explaining the differences between China and the West. Journal of Business Venturing, 18(2): 233-260. 
Bruton, G.D., Ahlstrom, D., \& Oblój, K. 2008. Entrepreneurship in emerging economies: Where are we today and where should the research go in the future. Entrepreneurship Theory and Practice, 32(1): 1-14.

Buckley, P. J., Clegg, J., \& Wang, C. 2002. The impact of inward FDI on the performance of Chinese manufacturing firms. Journal of International Business Studies, 33: 637-655.

Carlin, W., Schaffer, M. E. \& Seabright, P. 2004. A Minimum of Rivalry: Evidence from Transition Economies on the Importance of Competition for Innovation and Growth, C.E.P.R. Discussion Papers. CEPR Discussion Paper 4343. London: CEPR.

Casciaro, T., \& Piskorski, M. J. 2005. Power imbalance, mutual dependence, and constraint absorption: a closer look at resource dependence theory. Administrative Science Quarterly, 50(2): 167-199.

Cassiman, B., \& Veugelers, R. 2002. R\&D Cooperation and spillovers: Some empirical evidence from Belgium. American Economic Review, 92: 1169-1184.

Cassiman, B., \& Veugelers, R. 2006. In search of complementarity in innovation strategy: internal R\&D and external knowledge acquisition. Management Science, 52: 68-82.

Caves, R. E. 1974. Multinational firms, competition and productivity in host-country markets. Economica, 41(162): 176-193.

CCPIT. 2009. Survey on Current Conditions of and Intention for Outbound Investment by Chinese Enterprises, China Council for the Promotion of International Trade, Beijing

Certo, S. T., Daily, C. M., \& Dalton, D. R. 2001. Signaling firm value through board structure: An investigation of initial public offerings. Entrepreneurship Theory and Practice, 26: 33-50.

Chang, S. J., \& Park, S. 2012. Winning strategies in China: Competitive dynamics between MNCs and local firms. Long Range Planning, 45(1): 1-15.

Chang, S. J., \& Xu, D. 2008. Spillovers and competition among foreign and local firms in China. Strategic Management Journal, 29: 495-518.

Che, J., 2002. Rent seeking and government ownership of firms: an application to China's townshipvillage enterprises. Journal of Comparative Economics, 30: 781-811.

Chow, G. C. 1993. Capital formation and economic growth in China. Quarterly Journal of 
Economics, 108: 809-842.

Christensen, C. M., \& Bower, J. L. 1996. Customer power, strategic investment and the failure of leading firms. Strategic Management Journal, 17(3):197-218.

Christensen, C., Horn, M., \& Johnson, C. 2008. Disrupting class: How disruptive innovation will change the way the world learns. New York: McGraw-Hill.

Cohen, J. E. 1988. Statistical Power Analysis for the Behavioral Sciences. Hillsdale, NJ: Lawrence Erlbaum Associates, Inc.

Cohen, W. M., \& Levinthal, D. A. 1989. Innovation and learning: The two faces of R\&D. Economic Journal, 99: 569-596.

Cohen, J., Cohen, P., West, S. G., \& Aiken, L. S. 2003. Applied multiple regression / correlation for the behavioral sciences. Mahwah, NJ: Lawrence Erlbaum Associates.

Collinson, S. 2013. The making of an innovative multinational firm: Chinese capability development through the acquisition of MG Rover, Birmingham Business School Discussion Paper Series, 2013-04.

Covin, J., \& Slevin, D. 1990. New venture strategic posture, structure, and performance: An industry life cycle analysis. Journal of Business Venturing, 5(2): 123-135.

D’Aveni, R. A. 1994. Hypercompetition. New York: Free Press.

De Bondt, R., \& Vandekerckhove, J. 2012. Reflections on the relation between Competition and innovation. Journal of Industry, Competition and Trade, 12: 7-19.

Deakins, D., \& Freel, M. S. 2009. Entrepreneurship and Small Firms (fifth edition). London, England: McGraw-Hill Education.

Dixit, A., \& Stiglitz, J. 1977. Monopolistic competition and optimum product diversity. American Economic Review, 67(3): 297-308.

Dobson, W., \& Safarian, A. E. 2008. The transition from imitation to innovation: An enquiry into China’s evolving institutions and firm capabilities. Journal of Asian Economics, 19(4): 301311.

Driffield, N., \& Love, J. H. 2007. Linking FDI motivation and host economy productivity effects: Conceptual and empirical analysis. Journal of International Business Studies, 38(3): 460- 
473.Eapen, A. 2013. FDI spillover effects in incomplete datasets. Journal of International Business Studies, 44: 719-744

Emerson, R. M. 1962. Power-dependence relations. American Sociological Review, 27(1): 31-41.

Engels, F., \& Hunt, T. 2010. The origin of the family, private property and the state. New York, NY, USA: Penguin Group.

Escribano, A., Fosfuri, A., \& Tribó, J. A. 2009. Managing external knowledge flows: the moderating role of absorptive capacity. Research Policy, 39: 96-105.

Fan, J. P. H., Huang, J., Morck, R, \& Yeung, B. 2009. Vertical Integration, Institutional Determinants and Impact: Evidence from China. NBER Working Paper (14650).

Feinberg, S. E., \& Majumdar, S. K. 2001. Technology spillovers from foreign direct investment in the Indian pharmaceutical industry. Journal of International Business Studies, 32(3): 421-437.

Gao, G. Y., Murray, J. Y., Kotabe, M., \& Lu, J. 2010. A strategy tripod perspective on export behaviors: Evidence from domestic and foreign firms based in an emerging economy, Journal of International Business Studies, 41: 377-396.

Gavetti, G., \& Levinthal, D. 2000. Looking forward and looking backward: Cognitive and experiential search. Administrative Science Quarterly, 45(1): 113-137.

Garud, R., Jain, S. \& Kumaraswamy, A. 2002. Institutional entrepreneurship in the sponsorship of common technological standards: The case of Sun Microsystems and Java. Academy of Management Journal, 45(1): 196-214.

Ghoshal, S. 1987. Global strategy: An organizing framework. Strategic Management Journal, 8: 425440.

Gorg, H., \& Strobl, E. 2001. Multinational companies and productivity spillovers: A meta-analysis. The Economic Journal, 111(475): F723-F739.

Gorodnichenko, Y., Svejnar, J., \& Terrell, K. 2010. Globalization and innovation in emerging markets. American Economic Journal, 2: 194-226.

Greenaway, D., \& Kneller, R. 2007. Firm heterogeneity, exporting and foreign direct investment. The Economic Journal, 117: F134-F161 
Greenaway, D., Morgan, W., \& Wright, P. 2002. Trade liberalisation and growth in developing countries. Journal of Development Economic, 67: 229-244.

Groenendijk, T., Janssen, T., Gert Rijlaarsdam, G., \& Van Den Bergh, H. 2013. Learning to be creative. The effects of observational learning on students' design products and processes. Learning and Instruction, 28: 35-47.

Gulati, R., \& Sytch, M. 2007. Dependence asymmetry and joint dependence in interorganizational relationships: effects of embeddedness on a manufacturer's performance in procurement relationships. Administrative Science Quarterly, 52(1):32-69.

Haddad, M., \& Harrison, A. 1993. Are there positive spillovers from direct foreign investment? Evidence from panel data for Morocco. Journal of Development Economics, 42(1): 51-74.

Hafsi, T., \& Koenig, C. 1988. The state-SOE relationship: some patterns. Journal of Management Studies, 25(3): 235-249.

Haskel, J. E., Pereira, S., \& Slaughter, M. J. 2007. Does inward foreign direct investment boost the productivity of domestic firms? Review of Economics and Statistics, 89(3): 482-496.

Hatzichronoglou, T. 1997. Revision of the High-Technology Sector and Product Classification, OECD Science, Technology and Industry Working Papers, 1997/2, OECD Publishing. Haveman, H.A., Jia, N., Shi, J. \& Wang, Y. X. 2016.The Dynamics of Political Embeddedness in China, Administrative Science Quarterly, doi: 10.1177/0001839216657311

He, Z. L., \& Wong, P. K. 2004. Exploration vs. exploitation: An empirical test of the ambidexterity hypothesis. Organization Science, 15: 481-494.

Hillman, A. J., Withers, M. C., \& Collins, B. J. 2009. Resource Dependence Theory: A Review. Journal of Management, 35(6): 1404-1427.

Hinloopen J., \& Vandekerckhove, J. 2009. Dynamic efficiency of Cournot and Bertrand competition: input versus output spillovers. Journal of Economics, 98:119-136.

Hoskisson, R., Wright, M., Filatotchev, I., \& Peng, M. 2013. Emerging multinationals from midrange economies: The influence of institutions and factor markets. Journal of Management Studies, 50(7): 1295-1321. 
Howell, A. 2016. Firm R\&D, innovation and easing financial constraints in China: Does corporate tax reform matter? Research Policy, 45(10): 1996-2007.

Hymer, S. H. 1960. The international operation of national firms: a study of direct foreign investment. Ph.D. dissertation, MIT.

Inkpen, A. C., \& Beamish, P. W. 1997. Knowledge, bargaining power, and instability of international joint ventures. Academy of Management Review, 22(1): 177-202.

Jia, N., \& Mayer, K. J. 2017. Political hazards and firms’ geographic concentration, Strategic Management Journal, 38(2): 203-231.

Jorde, T. M., \& Teece, D. J. 1989. Competition and cooperation: Striking the right balance. California Management Review, 31(3): 25-37.

Kale, D., \& Little, S. 2007. From imitation to innovation: The evolution of R\&D capabilities and learning processes in the Indian pharmaceutical industry. Technology Analysis \& Strategic Management, 19: 589-609.

Kaplan, T. R., Luski, I., \& Wettstein, D. 2003, Innovative activity and sunk cost, International Journal of Industrial Organization, 21: 1111-1133.

Katila, R., \& Shane, S. 2005. When does lack of resources make new firms innovative. Academy of Management Journal, 48(5): 814-829.

Kogut, B., \& Zander, U. 1995. Knowledge, market failure and the multinational enterprise: A reply. Journal of International Business Studies, 26: 417-426.

Kotabe, M., Srinivasan, S., \& Aulakh, P. S. 2002. Multinationality and firm performance: The moderating role of R\&D and marketing capabilities. Journal of International Business Studies, 33(1): 79-97.

Kraatz, M. S., \& Jajac, E. J. 2001. How organizational resources affect strategic change and performance in turbulent environments: Theory and evidence. Organization Science, 12(5): 632-657.

Lado, A. A., Boyd, N. G., Wright, P., \& Kroll, M. 2006. Paradox and theorizing within the resourcebased view, Academy of Management Review, 31: 115-131. 
Lane, P. J., \& Lubatkin, M. L.1998. Relative absorptive capacity and interorganizational learning. Strategic Management Journal, 19: 461-477.

Leiponen, A., \& Helfat, C. E. 2010. Innovation objectives, knowledge sources, and benefits of breadth. Strategic Management Journal, 31(2): 224-236.

Li, H., \& Atuahene-Gima, K. 2002. The adoption of agency business activity, product innovation, and performance in Chinese technology ventures. Strategic Management Journal, 23(6): 469490.

Liu, X., \& Buck, T. 2007. Innovation performance and channels for international technology spillovers: Evidence from Chinese high-tech industries. Research Policy, 36(3): 355-366.

Liu, X., Wang, C., \& Wei, Y. 2009. Do local manufacturing firms benefit from transactional linkages with multinational enterprises in China. Journal of International Business Studies, 40(7): $1113-1130$.

Ma, X., \& Delios, A. 2010. Host-country headquarters and an MNE’s subsequent within-country diversifications. Journal of International Business Studies, 41: 517-525.

McMillan, J., \& Woodruff, C. 2002. The central role of entrepreneurs in transition economies. Journal of Economic Perspectives, 16(3): 153-170. Mirowski, P., \& Plehwe, D. 2009. The Road to Mont Pèlerin: The Making of the Neoliberal Thought Collective. Cambridge MA: Harvard University Press.

Mourdoukoutas, P. 2015. Business Strategy in a Semiglobal Economy. New York: Routledge.

Mueller, V., Rosenbusch, N., \& Bausch, A. 2013. Success Patterns of Exploratory and Exploitative Innovation: A Meta-Analysis of the Influence of Institutional Factors. Journal of Product and Innovation Management, 39: 1606-1636.

Nachum, L. 2010. When Is Foreignness an Asset or a Liability? Explaining the Performance Differential Between Foreign and Local Firms, Journal of Product and Innovation Management, 36: 714-739.

Nee, V., \& Mathews, R. 1996. Market transition and societal transformation in reforming state socialism, Annual Review of Sociology, 22: 401-435.

Nickell, S. J. 1996. Competition and corporate performance. Journal of Political Economy, 104: 724- 
746.

North, D. C. 1990. Institutions, institutional change and economic performance. Cambridge, England: Cambridge University Press.

Pan, Y., Li, S., \& Tse, D. K. 1999. Performance of foreign enterprises in China: The impact of order and mode of market entry. Journal of International Business Studies, 30: 81-104.

Park, S., \& Bae, Z. T. 2004. New venture strategies in a developing country: Identifying a typology and examining growth patterns through case studies. Journal of Business Venturing, 19: 81105.

Park, S. H., Li, S., \& Tse, D. K. 2006. Market liberalization and firm performance during China’s economic transition. Journal of International Business Studies, 37: 127-147.

Peng, M. W. 2003. Institutional transitions and strategic choices. Academy of Management Review, 28(2): 275-296.

Perri, A., \& Peruffo, E. 2016. Knowledge spillovers from FDI: A Critical review from the international business perspective, International Journal of Management Reviews, 18(1): 327.

Pfeffer, J. 1972. Interorganizational influence and managerial attitudes. Academy of Management Journal, 15(3): 317-330.

Pfeffer, J. 1976. Beyond management and the worker: The institutional function of management. Academy of Management Review, 1: 36-46.

Pfeffer, J., \& Salancik, G. R. 1978. The External Control of Organizations: A Resource Dependence Perspective. Stanford University Press: Stanford, CA.

Pfeffer, J., \& Salancik, G. R. 2003. The External Control of Organizations: A Resource Dependence Perspective (reissue). Stanford University Press: Stanford, CA.

Polder, M., \& Veldhuizen, E. 2012. Innovation and competition in the Netherlands: Testing the inverted-U for industries and firms. Journal of Industry, Competition and Trade, 12: 67-91

Prashantham, S., \& Birkinshaw, J. 2008. Dancing with Gorillas: how small companies can partner effectively with MNCs. California Management Review, 51: 6-23. 
Prashantham, S., \& Dhanaraj, C. 2015. MNE ties and new venture internationalization: Exploratory insights from India, Asia Pacific Journal of Management, 32: 901-924.

Salop, S. 1977. The noisy monopolist: imperfect information, price dispersion, and price discrimination. Review of Economic Studies, 44: 393-406.

Selya, A. S., Rose, J. S., Dierker, L. C., Hedeker, D., \& Mermelstein, R. J. 2012. A practical guide to calculating Cohen'S F2: A measure of local effect size from PROC MIXED. Frontiers in Psychology, 3: 111.

Schumpeter, J. A. 1950. Capitalism, socialism, and democracy (3rd ed.). New York: Harper.

Scott, W. R. 1995. Institutions and organizations. London: Sage.

Shepherd, D. A. 1999. Venture capitalists' assessment of new venture survival. Management Science, 45: 621-532.

Spencer, J. W. 2008. The impact of multinational enterprise strategy on indigenous enterprises: Horizontal spillovers and crowding out effects in developing countries. Academy of Management Review, 33: 341-361.

Storey, D., \& Greene, F. J. 2010. Small business and entrepreneurship. Harlow : Financial Times Prentice Hall

Sutton, J. 2007. Quality, Trade and the Moving Window: The Globalization Process. The Economic Journal, 117: F469-F498.

Szamosszegi, A., \& Kyle, C. 2011. An analysis of state-owned enterprises and state capitalism in China. U.S.-China Economic and Security Review Commission.

Szulanski G. 1996. Exploring internal stickiness: impediments to the transfer of best-practice within the firm. Strategic Management Journal, 17: 27-43.

Tan, J., \& Peng, M. 2003. Organizational slack and firm performance during economic transitions: two studies from an emerging economy, Strategic Management Journal, 24: 1249-1263.

Tang, J. 2006. Competition and Innovation Behaviour. Research Policy, 35: 68-82.

Tian, L., \& Estrin, S. 2008. Retained state shareholding in Chinese PLCs: Does government ownership always reduce corporate value? Journal of Comparative Economics, 36(1): 74-89. 
Tian, X. 2007. Accounting for sources of FDI technology spillovers: Evidence from China. Journal of International Business Studies, 38: 147-159.

Tomlinson, P. R., \& Jackson, I. 2013. Cooperative ties and the impact of external factors upon innovation in an industrial district: Some insights from the North Staffordshire table and giftware sector. Regional Studies, 47: 580-596.

The Economist. 2012. The state advances, in the Economist. Shanghai, October $6^{\text {th }} 2012$.

Tsang, E. W. K. 2002. Acquiring knowledge by foreign partners for international joint ventures in a transition economy: learning-by-doing and learning myopia. Strategic Management Journal, 23: 835-854.

Un, C. 2016. The liability of localness in innovation. Journal of International Business Studies, 47(1): $44-67$.

Wei, Y., \& Liu, X. 2006. Productivity spillovers from R\&D, exports and FDI in China's manufacturing sector. Journal of International Business Studies, 37: 544-557.

Wei, Y., Liu, X., \& Wang, C. 2008. Mutual productivity spillovers between foreign and local firms in China. Cambridge Journal of Economics, 32(4): 609-631.

White, S. 2000. Competition, capabilities, and the make, buy, or ally decisions of Chinese stateowned firms. Academy of Management Journal, 43(3): 324-341.

Wiersema, M. F., \& Bowen, H. P., 2008. Corporate diversification: The impact of foreign competition, industry globalization, and product diversification. Strategic Management Journal, 29: 115-132.

Williamson, P. J., \& Yin, E. 2014. Accelerated innovation: the new challenge from China, MIT Sloan Management Review, 55(4): 1-8.

Wooldridge, J. M. 2003. Introductory econometrics. Mason, OH: Thomas South-Western.

World Bank. 2010. Doing business 2011: China - making a difference for entrepreneurs: comparing business regulation in 183 economies. Washington, DC: World Bank.

Wu, Y. 2012, R\&D Behaviour in Chinese Firms, Discussion Paper series, Economics, UWA Business School, University of Western Australia.

Xia, J., Ma, X., Lu, J., \& Yiu, D. 2014. Outward foreign direct investment by emerging market firms: 
A resource dependence logic. Strategic Management Journal, 35(9): 1343-1363.

Xu, E., \& Zhang, H. 2008. The impact of state shares on corporate innovation strategy and performance in China. Asia Pacific Journal of Management, 25: 473-487.

Yamakawa, Y., Peng, M. W., \& Deeds, D. L. 2008. What drives new ventures to internationalize from emerging to developed economies? Entrepreneurship Theory and Practice, 32(1): 59-82.

Yi, J., \& Wang, C. 2012. The decision to export: Firm heterogeneity, sunk costs, and spatial concentration. International Business Review, 21(5): 766-781.

Yip, G. S., \& McKern, B. 2016. China’s next strategic advantage: From imitation to innovation. Cambridge, MT: The MIT Press.

Zhang, H. 2015. How Does Agglomeration Promote the Product Innovation of Chinese Firms? China Economic Review, 35: 105-120.

Zhang, Y., Li, H., Li, Y., \& Zhou, L. 2010. FDI spillovers in an emerging market: the role of foreign firms' country origin diversity and domestic firms' absorptive capacity. Strategic Management Journal, 31: 969-989.

Zhang, Y., Li, Y., \& Li, H. Y. 2014. FDI spillovers over time in an emerging market: the roles of entry tenure and barriers to imitation. Academy of Management Journal, 57: 698-722.

Zhao, Z., Anand, J., \& Mitchell, W. 2005. A dual networks perspective on inter-organizational transfer of R\&D capabilities: international joint ventures in the Chinese automotive industry. Journal of Management Studies, 42(1), 127-160.

Zhou, K. Z. 2006. Innovation, imitation, and new product performance: the case of China. Industrial Marketing Management, 35: 394-402.

Zhou, L., Wu, W. P., \& Luo, X. 2007. Internationalization and the performance of born-global SMEs: the mediating role of social networks. Journal of International Business Studies, 38: 673-690. 


\section{Table 1 Descriptive statistics and correlations}

\begin{tabular}{|c|c|c|c|c|c|c|c|c|c|c|c|c|c|c|c|}
\hline Variable & Mean & S.D. & 1 & 2 & 3 & 4 & 5 & 6 & 7 & 8 & 9 & 10 & 11 & 12 & 13 \\
\hline 1. Log(percentage of NPD sales) & 0.19 & 0.83 & 1 & & & & & & & & & & & & \\
\hline 2. Log (Innovation efforts) $)_{t-1}$ & 0.21 & 0.51 & 0.13 & 1 & & & & & & & & & & & \\
\hline 3. Log (Commercial effort $)_{t-1}$ & 0.21 & 0.5 & 0.1 & 0.13 & 1 & & & & & & & & & & \\
\hline 4. Export intensity ${ }_{t-1}$ & 0.18 & 0.8 & 0.12 & -0.02 & -0.03 & 1 & & & & & & & & & \\
\hline 5. Firm age $e_{t-1}$ & 7.22 & 2.95 & -0.13 & -0.07 & -0.02 & -0.17 & 1 & & & & & & & & \\
\hline 6. Capital intensity (Per firm) $)_{t-1}$ & 101.43 & 161.8 & -0.03 & -0.02 & 0.13 & -0.07 & 0.08 & 1 & & & & & & & \\
\hline 7. Firm Size t-1 $_{1}$ & 142.97 & 107.32 & 0.07 & -0.04 & 0.11 & 0.03 & 0.05 & -0.05 & 1 & & & & & & \\
\hline 8. Foreign competition ${ }_{t-1}$ & 12.6 & 1.58 & 0 & -0.07 & -0.06 & 0.06 & -0.06 & -0.04 & -0.03 & 1 & & & & & \\
\hline 9. SOE competition ${ }_{t-1}$ & 13.42 & 6.27 & 0.06 & -0.02 & 0.01 & 0.04 & 0 & 0.01 & -0.01 & 0.07 & 1 & & & & \\
\hline 10. Foreign spillover ${ }_{t-1}$ & 0.39 & 0.2 & -0.07 & -0.06 & -0.04 & -0.04 & 0.14 & 0.01 & -0.01 & 0.23 & 0.28 & 1 & & & \\
\hline 11. Private sector development $t_{t-1}$ & 9.61 & 2.67 & -0.08 & -0.1 & -0.17 & 0.08 & 0.22 & -0.05 & 0.02 & 0.03 & 0 & 0.08 & 1 & & \\
\hline $\begin{array}{l}\text { 12. The development of market-based } \\
\text { economy } t-1\end{array}$ & 9.19 & 1.19 & -0.08 & -0.1 & -0.14 & 0.07 & 0.2 & -0.06 & 0.04 & 0.04 & 0.01 & 0.06 & 0.38 & 1 & \\
\hline $\begin{array}{l}\text { 13. Local government support for } \\
\text { innvoation }_{t-1}\end{array}$ & 7.33 & 3.08 & -0.01 & -0.1 & -0.12 & 0.07 & 0.08 & -0.06 & -0.01 & 0.04 & 0.07 & 0.02 & 0.22 & 0.47 & 1 \\
\hline
\end{tabular}

Note: $\mathrm{N}=4,830$. $\mathrm{t}=7$. All positive and negative correlations greater than 0.027 are significant at $\mathrm{p}<0.05$. 
Table 2 Descriptive statistics by industry

\begin{tabular}{|c|c|c|c|c|c|c|c|c|}
\hline \multirow[t]{2}{*}{ Variable } & \multicolumn{2}{|c|}{$\begin{array}{c}\text { Industry } 1 \\
\text { (193 firms) }\end{array}$} & \multicolumn{2}{|c|}{$\begin{array}{c}\text { Industry } 2 \\
\text { (103 firms) }\end{array}$} & \multicolumn{2}{|c|}{$\begin{array}{c}\text { Industry } 3 \\
\text { (189 firms) }\end{array}$} & \multicolumn{2}{|c|}{$\begin{array}{c}\text { Industry } 4 \\
\text { (320 firms) }\end{array}$} \\
\hline & Mean & S.D. & Mean & S.D. & Mean & S.D. & Mean & S.D. \\
\hline \multicolumn{9}{|l|}{ Firm level } \\
\hline Log(percentage of NPD sales) & 0.22 & 0.90 & 0.24 & 0.96 & 0.15 & 0.72 & 0.17 & 0.79 \\
\hline Log (Innovation efforts) $)_{t-1}$ & 0.25 & 0.53 & 0.30 & 0.66 & 0.20 & 0.52 & 0.17 & 0.43 \\
\hline $\log (\text { Commercial effort })_{t-1}$ & 0.24 & 0.55 & 0.23 & 0.55 & 0.18 & 0.44 & 0.19 & 0.47 \\
\hline Export intensity $_{t-1}$ & 0.15 & 0.73 & 0.18 & 0.78 & 0.15 & 0.70 & 0.23 & 0.90 \\
\hline Firm age $_{t-1}$ & 7.06 & 2.94 & 7.32 & 2.94 & 7.55 & 2.94 & 7.09 & 2.94 \\
\hline Capital intensity (Per firm) $)_{t-1}$ & 104.10 & 185.45 & 109.72 & 167.10 & 104.10 & 162.33 & 95.54 & 143.28 \\
\hline Firm Size t-1 $_{\text {- }}$ & 149.05 & 108.35 & 142.49 & 104.24 & 138.70 & 106.16 & 142.03 & 108.27 \\
\hline \multicolumn{9}{|l|}{ Industry level } \\
\hline Foreign competition $_{t-1}$ & 10.93 & 0.48 & 11.26 & 1.03 & 14.05 & 1.01 & 13.24 & 0.99 \\
\hline SOE competition $_{t-1}$ & 10.64 & 2.70 & 12.50 & 1.54 & 17.86 & 6.79 & 12.8 & 6.13 \\
\hline Foreign spillover $_{t-1}$ & 0.22 & 0.05 & 0.19 & 0.09 & 0.66 & 0.11 & 0.41 & 0.13 \\
\hline \multicolumn{9}{|l|}{ Province level } \\
\hline Private sector development $t_{t-1}$ & 9.34 & 2.89 & 9.52 & 2.72 & 9.63 & 2.64 & 9.78 & 2.53 \\
\hline $\begin{array}{l}\text { The development of market- } \\
\text { based economy } \\
\text { Local government support for }\end{array}$ & 9.11 & 1.22 & 9.14 & 1.26 & 9.20 & 1.20 & 9.24 & 1.14 \\
\hline innovation $_{t-1}$ & 7.29 & 3.17 & 7.23 & 3.16 & 7.35 & 3.07 & 7.37 & 3.00 \\
\hline
\end{tabular}

" 1 ” = the pharmaceutical industry; " "2" = the medical, precision and optical instrument industry;

" 3 " = the office, accounting and computing machinery industry; "4" = the radio, TV and communications equipment industry. 
Table 3 Estimate of innovation performance, multi-level random intercept model ${ }^{\mathrm{a}}$

\begin{tabular}{|c|c|c|c|c|c|}
\hline Independent variable & $\begin{array}{l}\text { del } 1 \\
\text { Coef. } \\
\end{array}$ & $\begin{array}{r}\text { Model } 2 \\
\text { Coef. } \\
\end{array}$ & $\begin{array}{r}\text { Model } 3 \\
\text { Coef. } \\
\end{array}$ & $\begin{array}{r}\text { Model } 4 \\
\text { Coef. } \\
\end{array}$ & $\begin{array}{r}\text { Model } 5 \\
\text { Coef. } \\
\end{array}$ \\
\hline \multicolumn{6}{|l|}{ Firm level variables } \\
\hline Log (Innovation efforts ${ }_{t-1}$ ) & $\begin{array}{l}0.111^{* * *} \\
(0.016)\end{array}$ & $\begin{array}{l}0.112 * * * \\
(0.016)\end{array}$ & $\begin{array}{l}0.102^{* * *} \\
(0.017)\end{array}$ & $\begin{array}{l}0.102 * * * \\
(0.017)\end{array}$ & $\begin{array}{l}0.103^{* * *} \\
(0.017)\end{array}$ \\
\hline Log (Commercial efforts $\left.{ }_{t-1}\right)$ & $\begin{array}{l}0.074^{* *} \\
(0.023)\end{array}$ & $\begin{array}{l}0.067^{* *} \\
(0.023)\end{array}$ & $\begin{array}{l}0.077^{* *} \\
(0.024)\end{array}$ & $\begin{array}{l}0.076^{* *} \\
(0.024)\end{array}$ & $\begin{array}{l}0.077^{* *} \\
(0.024)\end{array}$ \\
\hline Export intensity $_{t-1}$ & $\begin{array}{l}0.090 * * * \\
(0.010)\end{array}$ & $\begin{array}{l}0.089 * * * \\
(0.010)\end{array}$ & $\begin{array}{l}0.086^{* * *} \\
(0.011)\end{array}$ & $\begin{array}{l}0.088^{* * *} \\
(0.011)\end{array}$ & $\begin{array}{l}0.083^{* * *} \\
(0.011)\end{array}$ \\
\hline Capital intensity (per firm) $)_{t-1}$ & $\begin{array}{l}0.000 * * * \\
(0.000)\end{array}$ & $\begin{array}{l}0.000^{* * *} \\
(0.000)\end{array}$ & $\begin{array}{l}0.000^{* * *} \\
(0.000)\end{array}$ & $\begin{array}{l}0.000^{* * *} \\
(0.000)\end{array}$ & $\begin{array}{l}0.000^{* * *} \\
(0.000)\end{array}$ \\
\hline Firm age $\mathrm{e}_{t-1}$ & $\begin{array}{l}-0.018^{* * *} \\
(0.003)\end{array}$ & $\begin{array}{l}-0.012^{* * *} \\
(0.003)\end{array}$ & $\begin{array}{l}-0.010 * * \\
(0.003)\end{array}$ & $\begin{array}{l}-0.001^{* * *} \\
(0.003)\end{array}$ & $\begin{array}{l}-0.009 * * \\
(0.003)\end{array}$ \\
\hline Firm size $_{t-1}$ & $\begin{array}{c}0.000 \\
(0.000)\end{array}$ & $\begin{array}{c}0.000 \\
(0.000)\end{array}$ & $\begin{array}{c}0.000 \\
(0.000)\end{array}$ & $\begin{array}{c}0.000 \\
(0.000)\end{array}$ & $\begin{array}{c}0.000 \\
(0.000)\end{array}$ \\
\hline \multicolumn{6}{|l|}{ Province level variables } \\
\hline \multicolumn{2}{|l|}{$\begin{array}{l}\text { Local government support } \\
\text { for innovation } \\
t-1\end{array}$} & $\begin{array}{l}0.019 * * * \\
(0.004)\end{array}$ & $\begin{array}{l}0.021^{* * *} \\
(0.005)\end{array}$ & $\begin{array}{l}0.020^{* * *} \\
(0.005)\end{array}$ & $\begin{array}{l}0.017^{* * *} \\
(0.005)\end{array}$ \\
\hline \multicolumn{2}{|l|}{ Private sector development $t_{t-1}$} & $\begin{array}{l}-0.038^{* * *} \\
(0.008)\end{array}$ & $\begin{array}{l}-0.049 * * * \\
(0.010\end{array}$ & $\begin{array}{l}-0.051^{* * *} \\
(0.010)\end{array}$ & $\begin{array}{l}-0.052^{* * *} \\
(0.010)\end{array}$ \\
\hline \multicolumn{2}{|l|}{$\begin{array}{l}\text { The development of market-based } \\
\text { economy } t_{t-1}\end{array}$} & $\begin{array}{c}0.0033 \\
(0.014)\end{array}$ & $\begin{array}{c}0.016 \\
(0.016)\end{array}$ & $\begin{array}{c}0.015 \\
(0.016)\end{array}$ & $\begin{array}{c}0.012 \\
(0.016)\end{array}$ \\
\hline \multicolumn{6}{|l|}{ Industry level variables } \\
\hline \multicolumn{2}{|l|}{ Foreign spillover $r_{t-1}$} & & $\begin{array}{l}-0.132^{* *} \\
(0.054)\end{array}$ & $\begin{array}{l}-0.198 * * * \\
(0.061)\end{array}$ & $\begin{array}{l}-0.165^{* * *} \\
(0.069)\end{array}$ \\
\hline \multicolumn{2}{|l|}{ Foreign competition $_{t-1}(\mathrm{FC})$} & & $-0.169 *$ & $0.014^{*}$ & $-0.323 * *$ \\
\hline \multicolumn{2}{|l|}{ Hypothesis 1} & & $(0.075)$ & $(0.007)$ & $(0.089)$ \\
\hline \multicolumn{2}{|l|}{$\begin{array}{l}\text { FC squared } \text { sq }_{t-1}(\mathrm{FC} 2) \\
\text { Hypothesis } 1\end{array}$} & & $\begin{array}{r}0.007 * \\
(0.003)\end{array}$ & & $\begin{array}{l}0.013^{* *} \\
(0.004)\end{array}$ \\
\hline \multicolumn{2}{|l|}{$\begin{array}{l}\text { SOE competition } \\
\text { t-1 } \\
\text { Hypothesis } 2\end{array}$} & & & $\begin{array}{r}0.003 * \\
(0.002)\end{array}$ & $\begin{array}{l}0.008^{* * *} \\
(0.002)\end{array}$ \\
\hline \multicolumn{6}{|l|}{$\mathrm{FC}_{t-1} \times \mathrm{SC}_{t-1}$} \\
\hline \multicolumn{6}{|l|}{$\mathrm{FC} 2_{t-1} \times \mathrm{SC}_{t-1}$} \\
\hline \multirow{2}{*}{\multicolumn{2}{|c|}{$\begin{array}{l}\text { Number of industry groups } \\
\text { Number of province groups }\end{array}$}} & & 4 & 4 & 4 \\
\hline & & 31 & 31 & 31 & 31 \\
\hline Number of obs. & 4,830 & 4,830 & 4,830 & 4,830 & 4,830 \\
\hline AIC & 14,300 & 14,270 & 12,771 & 12,772 & 12,764 \\
\hline Log likelihood & $-7,141$ & $-7,123$ & $-6,368$ & $-6,369$ & $-6,364$ \\
\hline $\begin{array}{l}\text { df } \\
\text { Significance of } \mathrm{FC}_{t-1}, \mathrm{FC} 2_{t-1} \\
\text { Random effect parameters } \\
\text { (variance) }\end{array}$ & 6 & 9 & $\begin{array}{l}12 \\
8.33^{* * *}\end{array}$ & 12 & $\begin{array}{c}13 \\
13.85^{* * *}\end{array}$ \\
\hline Firm level & & $\begin{array}{l}0.635^{* * *} \\
(0.797)\end{array}$ & $\begin{array}{l}0.633^{* * *} \\
(0.796)\end{array}$ & $\begin{array}{l}0.630 * * * \\
(0.794)\end{array}$ & $\begin{array}{l}0.627 * * * \\
(0.792)\end{array}$ \\
\hline Province level & & $\begin{array}{l}0.056^{* * *} \\
(0.237)\end{array}$ & $\begin{array}{l}0.050^{* * *} \\
(0.224)\end{array}$ & $\begin{array}{l}0.051^{* * *} \\
(0.225)\end{array}$ & $\begin{array}{l}0.051^{* * *} \\
(0.226)\end{array}$ \\
\hline Industry level & & & $\begin{array}{l}0.000^{* * *} \\
(0.000)\end{array}$ & $\begin{array}{l}0.000^{* * *} \\
(0.000)\end{array}$ & $\begin{array}{l}0.000^{* * * *} \\
(0.000)\end{array}$ \\
\hline
\end{tabular}

a All time varying independent variables are lagged by one year.

$\dagger$ if $\mathrm{p}<0.10$; $*$ if $\mathrm{p}<.05$; ** if $\mathrm{p}<.01$; *** if $\mathrm{p}<0.001$. 
" 1 " = the pharmaceutical industry; " 2 " = the medical, precision and optical instrument industry; " 3 " = the office, accounting and computing machinery industry; " 4 " = the radio, TV and communications equipment industry.

Figure 1 Distribution of SOEs, foreign firms and private HTNVs across each industry from 2001-2007 in the overall sampling frame

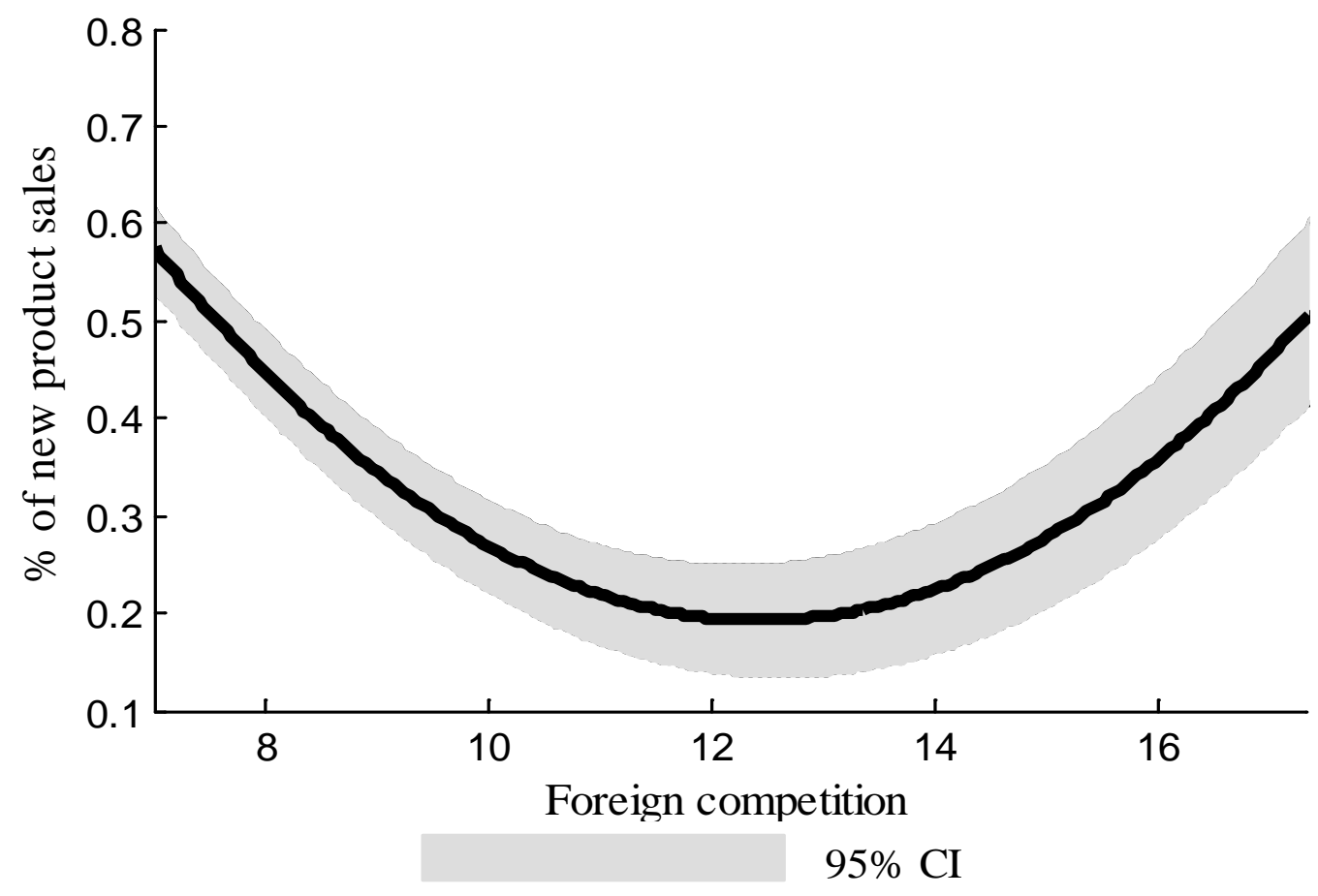

Figure 2 Direct effect of foreign competition 


\section{APPENDIX A}

Table A1 Estimate of innovation performance, multi-level random intercept model ${ }^{\mathrm{a}}$

\begin{tabular}{|c|c|}
\hline Independent variable & Coef. \\
\hline \multicolumn{2}{|l|}{ Firm level variables } \\
\hline Log (Innovation efforts ${ }_{t-1}$ ) & $\begin{array}{l}0.102 * * * \\
(0.017)\end{array}$ \\
\hline Log (Commercial efforts $\left.t_{t-1}\right)$ & $\begin{array}{l}0.078^{* *} \\
(0.024)\end{array}$ \\
\hline Export intensity $_{t-1}$ & $\begin{array}{l}0.077 * * * \\
(0.011)\end{array}$ \\
\hline Capital intensity (per firm) $)_{t-1}$ & $\begin{array}{l}0.000^{* * *} \\
(0.000)\end{array}$ \\
\hline Firm age $_{t-1}$ & $\begin{array}{l}-0.007 * * \\
(0.003)\end{array}$ \\
\hline Firm size $_{t-1}$ & $\begin{array}{c}0.000 \\
(0.000)\end{array}$ \\
\hline \multicolumn{2}{|l|}{ Province level variables } \\
\hline Local government support for innovation $t_{t-1}$ & $\begin{array}{l}0.015^{* *} \\
(0.005)\end{array}$ \\
\hline Private sector development $t_{t-1}$ & $\begin{array}{l}-0.051 * * * \\
(0.010)\end{array}$ \\
\hline The development of market-based economy ${ }_{t-1}$ & $\begin{array}{c}0.015 \\
(0.016)\end{array}$ \\
\hline \multicolumn{2}{|l|}{ Industry level variables } \\
\hline Foreign spillover $_{t-1}$ & $\begin{array}{l}-0.225^{* * *} \\
(0.057)\end{array}$ \\
\hline Foreign competition $_{t-1}(\mathrm{FC})$ & $-0.895 * *$ \\
\hline Hypothesis 1 & $(0.345)$ \\
\hline $\begin{array}{l}\text { FC squared } \\
\text { Hypothesis } 1\end{array}$ & $\begin{array}{l}0.036 * * \\
(0.013)\end{array}$ \\
\hline $\begin{array}{l}\text { SOE competition }{ }_{t-1}(\mathrm{SC}) \\
\text { Hypothesis } 2\end{array}$ & $\begin{array}{c}0.370^{*} \\
(0.204)\end{array}$ \\
\hline $\mathrm{FC}_{t-1} \times \mathrm{SC}_{t-1}$ & $\begin{array}{c}0.062 * \\
(0.031)\end{array}$ \\
\hline $\mathrm{FC} 2_{t-1} \times \mathrm{SC}_{t-1}$ & $\begin{array}{l}-0.002^{*} \\
(0.001)\end{array}$ \\
\hline Number of industry groups & 4 \\
\hline Number of province groups & 31 \\
\hline Number of obs. & 4,830 \\
\hline AIC & 12,746 \\
\hline Log likelihood & $-6,353$ \\
\hline Df & 15 \\
\hline $\begin{array}{l}\text { Significance of } \mathrm{FC}_{t-1}, \mathrm{FC} 2_{t-1} \\
\text { Random effect parameters (variance) }\end{array}$ & $27.77 * * *$ \\
\hline Firm level & $\begin{array}{l}0.620^{* * *} \\
(0.787)\end{array}$ \\
\hline Province level & $\begin{array}{l}0.051^{* * *} \\
(0.226)\end{array}$ \\
\hline Industry level & $\begin{array}{l}0.000^{* * *} \\
(0.000)\end{array}$ \\
\hline
\end{tabular}

a All time varying independent variables are lagged by one year.

$\dagger$ if $\mathrm{p}<0.10$; * if $\mathrm{p}<.05$;** if $\mathrm{p}<.01 ; * * *$ if $\mathrm{p}<0.001$ 


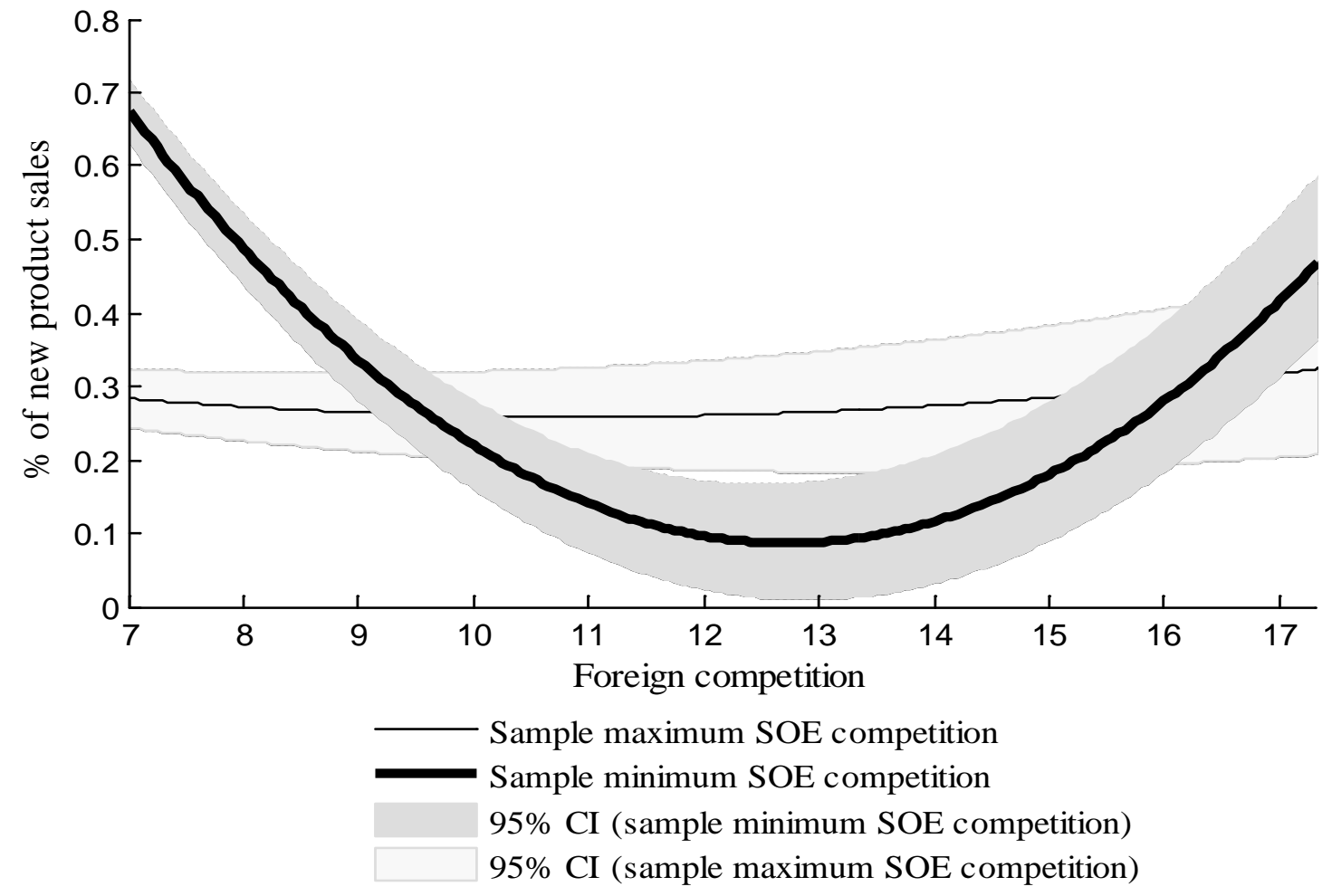

Figure B1 Moderating effects of SOE Competition 
APPENDIX C

Table C1 Estimate of novel innovation at industry level ${ }^{\mathrm{a}}$, Poisson model

\begin{tabular}{|c|c|}
\hline Industry level independent variable & Coef. \\
\hline Log (Innovation efforts ${ }_{t-1}$ ) & $\begin{array}{l}3.146 * * * \\
(0.005)\end{array}$ \\
\hline Log (Commercial efforts Com $\left._{1}\right)$ & $\begin{array}{c}-11.455^{* *} \\
(0.011)\end{array}$ \\
\hline Export intensity $y_{t-1}$ & $\begin{array}{l}23.407 * * * \\
(0.034)\end{array}$ \\
\hline Capital intensity (per firm) $)_{t-1}$ & $\begin{array}{l}0.010 * * * \\
(0.000)\end{array}$ \\
\hline Firm age $_{t-1}$ & $\begin{array}{l}0.403 * * * \\
(0.001)\end{array}$ \\
\hline Firm size $e_{t-1}$ & $\begin{array}{l}-0.004 \\
(0.000)\end{array}$ \\
\hline Local government support for innovation ${ }_{t-1}$ & $\begin{array}{l}0.045^{* * *} \\
(0.000)\end{array}$ \\
\hline Private sector development $t_{t-1}$ & $\begin{array}{l}0.078^{* * *} \\
(0.001)\end{array}$ \\
\hline The development of market-based economy $y_{t-1}$ & $\begin{array}{c}0.041 \\
(0.001)\end{array}$ \\
\hline Foreign spillover ${ }_{t-1}$ & $\begin{array}{l}-0.159 * * * \\
(0.003)\end{array}$ \\
\hline Foreign competition $_{t-1}(\mathrm{FC})$ & $7.433^{* * *}$ \\
\hline Hypothesis 1 & $(0.022)$ \\
\hline FC squared st- $_{1}(\mathrm{FC} 2)$ & $-0.244 * * *$ \\
\hline Hypothesis 1 & $(0.001)$ \\
\hline SOE competition $_{t-1}(\mathrm{SC})$ & $2.799 * * *$ \\
\hline Hypothesis 2 & $(0.013)$ \\
\hline $\mathrm{FC}_{t-1} \times \mathrm{SC}_{t-1}$ & $\begin{array}{l}0.513^{* * *} \\
(0.002)\end{array}$ \\
\hline $\mathrm{FC} 2_{t-1} \times \mathrm{SC}_{t-1}$ & $\begin{array}{l}-0.024 * * * \\
(0.000)\end{array}$ \\
\hline Number of obs. & 4,830 \\
\hline AIC & 18.40 \\
\hline $\begin{array}{l}\text { Log likelihood } \\
\text { Df }\end{array}$ & $\begin{array}{r}-45,052.95 \\
15\end{array}$ \\
\hline Significance of $\mathrm{FC}_{t-1} \mathrm{FC} 2_{t-1}$ & 764.92 \\
\hline
\end{tabular}

${ }^{\text {a }}$ All time varying independent variables are lagged by one year. All independent variables are at industry level.

$\dagger$ if $\mathrm{p}<0.10$; * if $\mathrm{p}<.05 ; * *$ if $\mathrm{p}<.01 ; * * *$ if $\mathrm{p}<0.001$. 